\title{
Effects of Arctic Sea Ice Decline on Weather and Climate: A Review
}

\author{
Timo Vihma
}

Received: 23 May 2013/ Accepted: 3 February 2014/Published online: 9 March 2014

(C) The Author(s) 2014. This article is published with open access at Springerlink.com

\begin{abstract}
The areal extent, concentration and thickness of sea ice in the Arctic Ocean and adjacent seas have strongly decreased during the recent decades, but cold, snow-rich winters have been common over mid-latitude land areas since 2005. A review is presented on studies addressing the local and remote effects of the sea ice decline on weather and climate. It is evident that the reduction in sea ice cover has increased the heat flux from the ocean to atmosphere in autumn and early winter. This has locally increased air temperature, moisture, and cloud cover and reduced the static stability in the lower troposphere. Several studies based on observations, atmospheric reanalyses, and model experiments suggest that the sea ice decline, together with increased snow cover in Eurasia, favours circulation patterns resembling the negative phase of the North Atlantic Oscillation and Arctic Oscillation. The suggested large-scale pressure patterns include a high over Eurasia, which favours cold winters in Europe and northeastern Eurasia. A high over the western and a low over the eastern North America have also been suggested, favouring advection of Arctic air masses to North America. Mid-latitude winter weather is, however, affected by several other factors, which generate a large inter-annual variability and often mask the effects of sea ice decline. In addition, the small sample of years with a large sea ice loss makes it difficult to distinguish the effects directly attributable to sea ice conditions. Several studies suggest that, with advancing global warming, cold winters in mid-latitude continents will no longer be common during the second half of the twenty-first century. Recent studies have also suggested causal links between the sea ice decline and summer precipitation in Europe, the Mediterranean, and East Asia.
\end{abstract}

Keywords Arctic $\cdot$ Climate change $\cdot$ Mid-latitude weather $\cdot$ Sea ice $\cdot$ Snow $\cdot$ Winter weather

T. Vihma $(\bowtie)$

Finnish Meteorological Institute, Erik Palmenin aukio 1, P.O. Box 503, 00101 Helsinki, Finland

e-mail: timo.vihma@fmi.fi 


\section{Introduction}

The climate change in the Arctic has been at least twice as fast as the global average (Blunden and Arndt 2012). One of the most dramatic indicators of the Arctic warming has been the decline in the sea ice cover. This has been manifested as a decrease in the ice extent, ice thickness, and the length of the ice season. Due to the availability of satellite passive microwave remote sensing data, the changes in ice extent have been reasonably well documented since 1979. The change has been most dramatic in summer and autumn, with approximately $50 \%$ decrease since the beginning of the satellite record. Related to the decreased ice extent, the period with sea ice cover has become remarkably shorter over large areas (Stammerjohn et al. 2012). Although data available on ice thickness are less accurate than that of ice extent, the first alerting signs of Arctic sea ice decline were from ice becoming thinner (Rothrock et al. 1999). Since 1980, the winter ice thickness in the central Arctic has decreased by approximately $1.8 \mathrm{~m}$, i.e. $50 \%$ (Kwok and Rothrock 2009). On the basis of coupled model experiments made in 18 climate centres, Overland et al. (2011a) estimate that an ice-free Arctic Ocean in September will occur around year 2050.

The Arctic sea ice cover is, however, not only a sensitive indicator of the climate change, but Arctic sea ice also has strong feedback effects on the other components of the climate system. Simultaneously, with the declining sea ice cover, the annual mean 2-m air temperature has increased over almost all weather stations north of $60^{\circ} \mathrm{N}$, with the strongest warming in coastal and archipelago areas surrounding the Arctic Ocean (Polyakov et al. 2012). Since the late 1980s, however, negative 2-m air temperature trends in winter have prevailed over large parts of northern Eurasia (Cohen et al. 2012a, b), and since 2005, several mid-latitude regions have experienced cold, snow-rich winters. For example, winter 2005-2006 was very cold in large parts of Europe and northern Asia (Petoukhov and Semenov 2010). Winter 2009-2010 was extremely cold in large parts of the northern mid-latitudes (Cohen et al. 2010) with the lowest North Atlantic Oscillation (NAO) index since winter 1824 (Cattiaux et al. 2010). Also, winter 2010-2011 was exceptionally cold in most of Europe (Osborn 2011), e.g., December 2010 was the coldest for over 100 years in the United Kingdom (Eden 2011). Furthermore, March 2013 was particularly cold in northern Europe, in fact the coldest March in 50 years in the UK. The cold, snow-rich winters, occurring despite global warming, have received a lot of public and scientific attention. Several scientific papers, to be reviewed here, have addressed the potential causal links between the Arctic sea ice decline and these cold winters in midlatitudes. In addition to the exceptional winters, large parts of central and northern Europe have recently experienced six consecutive wet summers, which is exceptional (Screen 2013). A few studies have addressed the potential links between the sea ice decline and rain fall in Europe, the Mediterranean, and East Asia.

The main characteristics of sea ice to affect the other components of the climate system are (a) prevention or reduction in the exchange of heat, momentum, water vapour, and other materia between the atmosphere and ocean and (b) much higher surface albedo than that of the open ocean. Hence, as the insulation reduces with declining sea ice cover, the ocean will lose more heat to the atmosphere. As the heat capacity of a unit volume of ocean water is about 3,600 times larger than that of the air, it is expected that temperature changes are much more detectable in the atmosphere, particularly in winter when the heat flux from the ocean is large. In addition, the reduced surface albedo results in heating of the ocean in summer, compensating for the increased heat loss, which occurs in other seasons. 
The effects of sea ice decline on the atmosphere can be divided into local and remote effects. Local effects are here defined as the effects that occur in regions that have during the recent decades lost their sea ice cover or where the sea ice has become thinner, whereas remote effects are those felt over continents or sea areas that have always (during the twentieth and twenty-first century) been ice free. The effects depend on the season. The expected direct local effects of sea ice decline are the increased turbulent fluxes of sensible and latent heat from the ocean to the atmosphere as well as increased longwave radiation emitted by the sea surface. The turbulent fluxes affect the air temperature and moisture, as well as the formation of clouds. The remote effects are much more complicated. The basic challenges are to understand (a) how does the mid-latitude circulation respond to changes in the Arctic, in the absence of other changes, and (b) which of the many forcing factors of mid-latitude weather dominate in different conditions.

Meier et al. (2011), Polyakov et al. (2012) and Stroeve et al. (2012) have reviewed the recent decline in Arctic sea ice and the processes responsible for it. The role of Arctic sea ice on the global atmospheric circulation has been reviewed by Budikova (2009), but numerous important studies have been published since that; analyses of the recent cold, snow-rich winters have generated a lot of new knowledge. Analyses that focused on the relationships between sea ice, storminess, and the NAO were reviewed by Bader et al. (2011). In this paper, I first summarize the observed changes in the Arctic sea ice cover and the present understanding on the reasons for them (Sect. 2). Then I address the local (Sect. 3) and remote (Sect. 4) effects of the sea ice decline by reviewing publications based on in situ and remote sensing observations, atmospheric reanalyses, and model experiments. Then, to put the results into a broader perspective, I address the links between the sea ice extent, Eurasian snow cover, and winter climate (Sect. 5). Section 6 is a critical evaluation of the reliability of the methods applied, followed by discussion and conclusions in Sects. 7 and 8.

\section{Sea Ice Decline}

Sea ice in the Arctic can be characterized by areal extent, thickness, age, and movement. The conditions on top of sea ice, such as the snow thickness and melt ponds, are also important. From the point of view of weather and climate, the most essential questions are (a) how much the area covered by sea ice has decreased, (b) how much the ice and snow thicknesses have decreased, and (c) how much the melting and ice-free periods have lengthened.

\subsection{Observed Changes in Sea Ice Concentration, Area, and Extent}

The terminology related to the aerial coverage of sea ice is closely linked to the observational techniques. Satellite remote sensing algorithms yield the fraction of the ocean surface covered by sea ice in a pixel of a certain size (the size depends on the remote sensing instrument). Sea ice concentration (SIC) is defined as the fraction covered by sea ice, and sea ice extent is defined as the cumulative area of all pixels having at least 10 or $15 \%$ SIC. The threshold of $10 \%$ (World Meteorological Organization 1970) originates from pre-satellite era, when the concentration was estimated for the area covered by visual observations. The $15 \%$ threshold is commonly applied by the remote sensing community and, among others, the U.S. National Snow and Ice Data Center (Parkinson and Cavalieri 2008). Sea ice area is the cumulative sum of the product of the pixel ice concentration and pixel area for all pixels having at least $15 \%$ (or $10 \%$ ) ice concentration. 


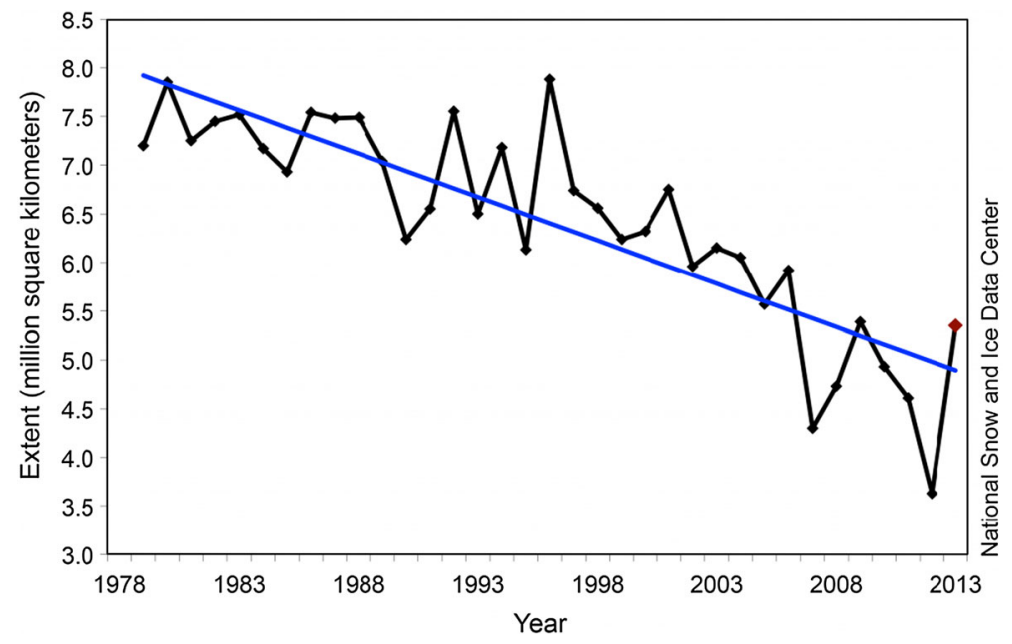

Fig. 1 Time series of September average sea ice extent in the period 1979-2013 on the basis of satellite passive microwave data. Image courtesy of the National Snow and Ice Data Center, University of Colorado, Boulder

Over the period 1979-2010, the Northern Hemisphere sea ice extent for September has decreased by more than $4 \%$ per decade (Cavalieri and Parkinson 2012). Figure 1 shows the time series of the September sea ice extent from 1979 to 2013. We see that the ice extent has decreased to approximately half of the values typical early in the period. For every year since 1996, the September ice extent has been less than the average from 1979 to 1999 , and the seven lowest September ice extents have all occurred during the past 7 years, 2007-2013. Winter ice extents are also declining, but at a slower rate. Since 2005, however, the winter (December-March) sea ice extent has been more than two standard deviations lower than the mean for 1979-2000 (www.nsidc.org). The reduction in the ice cover is particularly important in winter, when the thermal difference between the sea ice and open water is largest. The summer and autumn sea ice decline has been the strongest in the Arctic Ocean (in particular in the Chukchi, East Siberian, and Beaufort Seas), Kara and Barents Seas, and the Baffin Bay/Labrador Sea region (Fig. 2 illustrates the record minimum ice cover in September 2012). The winter decline has been the strongest in southern areas: the Greenland Sea, Kara and Barents Seas, Baffin Bay/Labrador Sea region, and the Sea of Okhotsk (Cavalieri and Parkinson 2012).

The steepening of the decreasing trend of September sea ice extent has received a lot of attention. Stroeve et al. (2007) showed that climate models have not been able to capture it, and Comiso et al. (2008) showed a statistically significant difference in linear regression slopes computed for the periods 1979-1996 and 1996-2007, respectively. Due to variations in ice concentration, the trends in ice area and ice extent have not been equal. From January through April, the sea ice area trends are even slightly positive for the Arctic Ocean and the Canadian Archipelago regions, related to an increase in SIC (Cavalieri and Parkinson 2012).

\subsection{Observed Changes in Ice Thickness}

Rothrock et al. (1999) compared the sea ice draft observations made during submarine cruises in 1993-1997 with similar data from 1958 to 1976; the mean ice draft at the end of the melt season had decreased from 3.1 to $1.8 \mathrm{~m}$. Later, using a combination of submarine 


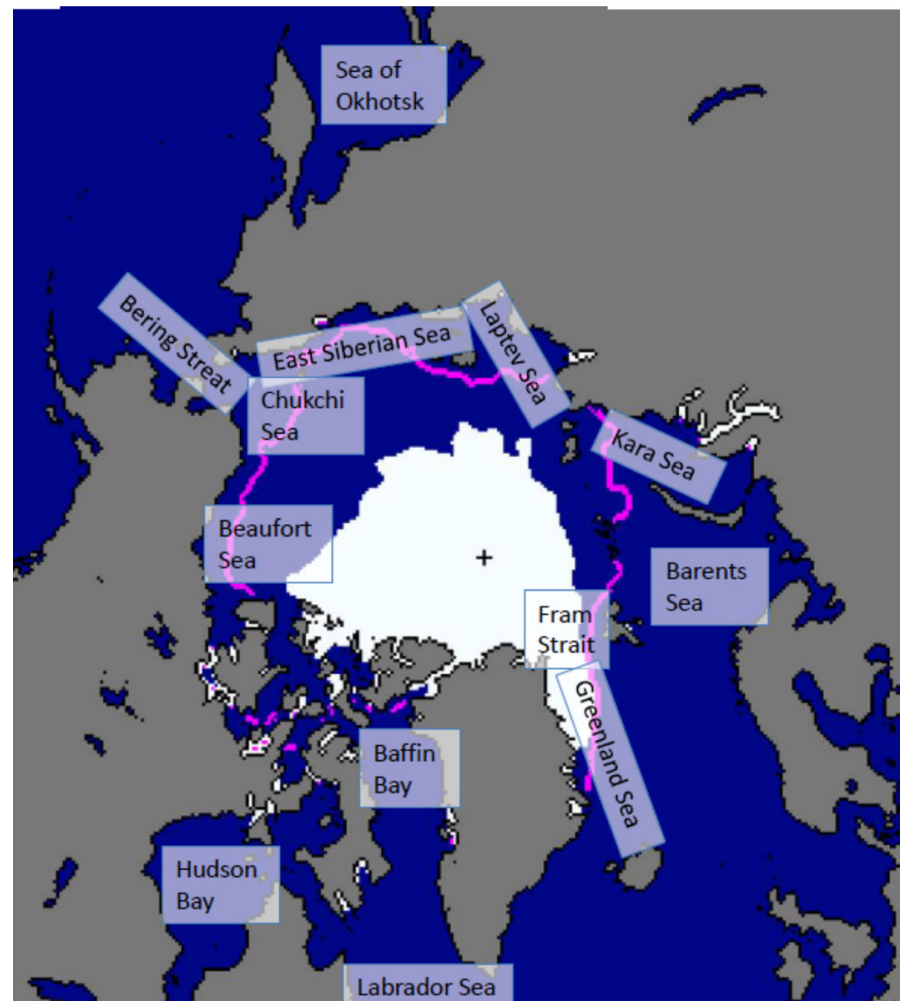

Fig. 2 Arctic sea ice extent in September 2012 (white area) compared with the median ice edge (purple line) in the period 1979-2012. Image courtesy of the National Snow and Ice Data Center, University of Colorado, Boulder. The names of sea areas added by the author

and satellite records, Kwok and Rothrock (2009) concluded that the mean winter ice thickness in the central Arctic has decreased by approximately $1.8 \mathrm{~m}$ since 1980 . The thinning had been fastest, $0.10-0.20 \mathrm{~m} \mathrm{year}^{-1}$, during the 5 years prior to their study. The decrease in the mean ice thickness is strongly related to the reduction in the area covered by multi-year ice (Polyakov et al. 2012). Already, in the early 1990s, the spring ice thickness distribution in the Arctic Ocean shifted towards a larger fraction of thin, first-year ice (Maslanik et al. 2007).

From the point of view of weather and climate, the sea ice thickness becomes increasingly important when there is very little or no snow on top of ice (e.g., Vihma et al. 2002; Cheng et al. 2013). On the basis of simple calculations applying piecewise linear temperature profiles in snow and ice (Makshtas 1991), it can be shown that when the snow pack is thick, say $0.3 \mathrm{~m}$, a major thinning of ice, e.g., from 3 to $1.5 \mathrm{~m}$ only has a small effect on the conductive flux from the ocean through ice and snow: an increase by some $3 \mathrm{~W} \mathrm{~m}^{-2}$ under typical Arctic winter conditions. In the case of bare ice, however, the same ice thinning would increase the flux by approximately $13 \mathrm{~W} \mathrm{~m}^{-2}$. Hence, snow thickness trends are at least as important for heat conduction as ice thickness trends. For snow, the most extensive information available is based on 37 years (1954-1991) of measurements made at Soviet drifting stations on multi-year ice (Radionov et al. 1996; Warren et al. 
1999), but no contemporary, systematic, basin-scale in situ observations of snow depth exist for Arctic Ocean sea ice (Farrell et al. 2012). Estimates based on remote sensing have, however, been developed (Brucker and Markus 2013).

Thin ice is more liable to melt and deform, and hence, the ice extent, area, and concentration may rapidly decrease. Hence, more solar radiation will be absorbed, and the sea will remain open later in autumn, with a large heat and moisture flux to the atmosphere (Stroeve et al. 2012).

\subsection{Observed Changes in the Ice-Free Period and Melting Season}

In those parts of the Arctic where the sea ice decrease is fastest, the sea ice retreat has in the recent years been nearly 2 months earlier and subsequent advance more than a month later than in 1979-1980, resulting in a three-month longer summer ice-free season (Stammerjohn et al. 2012). From the point of view of the atmosphere, another important variable is the length of the melt season, when the snow/ice surface temperature is fixed to $0{ }^{\circ} \mathrm{C}$ (with occasional slightly lower values). The spring onset of snow melt on sea ice reduces the snow albedo and initiates the positive feedback effect. An early melt onset tends to result in an early generation of open water areas, which favours heat accumulation in the upper ocean. Maksimovich and Vihma (2012) concluded that in the period of 1989-2008, local 20-year snow melt onset trends averaged over the central Arctic Ocean were towards earlier melt by 9 days per decade. The earlier melt onset has been due to higher air temperatures in spring (Belchansky et al. 2004) and, above all, increased downward longwave radiation (Maksimovich and Vihma 2012). In the autumn, ice cannot form over open water areas until the ocean mixed layer loses its heat. As a result, the freeze-up starts later, which contributes to sea ice thinning in the following year (Laxon et al. 2003; Notz 2009). The autumn freeze-up has become later everywhere in the Arctic (except in the Sea of Okhotsk), but the change has been smaller than in the spring melt onset. For autumn, the largest changes have been observed in the Laptev/East Siberian Seas and Chukchi/Beaufort Seas with trends between 6.9 and 8.4 days per decade (Markus et al. 2009).

\subsection{Reasons for the Sea Ice Decline}

Reasons for the Arctic sea ice decline have been addressed in numerous studies, with Meier et al. (2011), Stroeve et al. (2012) and Polyakov et al. (2012) providing up-to-date summaries. During the recent decades, the temporal and spatial changes in the atmospheric circulation have been essential factors directly affecting the sea ice decline (Zhang et al. 2008; Overland and Wang 2010). Overland and Wang (2010) concluded that a shift to a more meridional atmospheric pattern, the Arctic Dipole (AD), over the last decade contributed to recent reductions in summer Arctic sea ice extent. According to Polyakov et al. (2012), particularly the atmospheric thermodynamic forcing has played an increasingly important role. The advection of moist air masses from lower latitudes to the Arctic, the associated increase in downward longwave radiation, and its dependency on the cloud fraction, base height, and phase (liquid water or ice) have been addressed by, e.g., Francis and Hunter (2007) and Kapsch et al. (2013). As the ice thickness has decreased, the ice pack has become increasingly sensitive to the ice-albedo feedback (Perovich et al. 2008; Serreze et al. 2009). This is seen, among others, in more negative inter-annual trends in sea ice extent for later summer, when the albedo feedback lasts for a longer period, than for early summer (Stroeve et al. 2012). Furthermore, Screen and Simmonds (2012) concluded 
that the decline in summer snowfall has likely contributed to the thinning of sea ice over recent decades. The change from snowfall to rain has strongly increased the fraction of bare sea ice, which has a much lower albedo than snow-covered sea ice.

In addition to the decreasing trend in September ice extent, its inter-annual variability has strongly increased during recent years. Stroeve et al. (2012) argue that this is partly due to the thinning of the ice, as thin ice is more sensitive to variations in the atmospheric conditions in summer (Holland et al. 2008). Besides thermodynamic conditions, thinner ice is more sensitive to wind forcing, seen as increased ice drift speeds (Spreen et al. 2011; Vihma et al. 2012). Ice export out of the Arctic was large in late 1980s and early 1990s (Rigor and Wallace 2004), but according to Polyakov et al. (2012) it is unclear if it has played a significant role in the (multi-year) ice mass budget over the past decade.

Numerous studies have addressed the reasons for the record minimum September sea ice extents in 2007 and 2012. In 2007, a key driver of the record was an atmospheric pattern allowing large heat transport from the Pacific sector (Kay et al. 2008; L'Heureux et al. 2008; Stroeve et al. 2008; Perovich et al. 2008; Schweiger et al. 2008; Ogi et al. 2010; Graversen et al. 2011), but also an increased oceanic heat transport via the Bering Strait played a role (Woodgate et al. 2010). Kay et al. (2008) stressed the importance of large shortwave radiation in summer, whereas Graversen et al. (2011) concluded that the increased downward longwave radiation in spring was a major factor. The extent and area of Arctic sea ice reached a new record in September 2012 (Parkinson and Comiso 2013). This was partly due to a record-strong storm that occurred over the Beaufort Sea in early August (Simmonds and Rudeva 2012). The storm caused disintegration of a large part of the central Arctic sea ice pack. This part entirely melted, and the disintegration enhanced the melt of the remaining main ice pack (Parkinson and Comiso 2013). According to a modelling study by Zhang et al. (2013), the strong melt was largely due to a quadrupling in bottom melt, caused by storm-driven enhanced mixing in the ocean boundary layer. Zhang et al. (2013) argued that a record minimum ice extent would have been reached in 2012 even without the storm, as by early August the ice volume had already decreased $\sim 40 \%$ from the 2007-2011 mean.

The fast climate warming in the Arctic has accelerated the sea ice decline, but simultaneously, the sea ice decline has amplified the warming (e.g., Kumar et al. 2010). Among the many processes that have been considered responsible for the Arctic amplification of climate warming, the sea ice decline is associated with the snow/ice-albedo feedback effect (Flanner et al. 2011; Graversen and Wang 2009; Serreze and Barry 2011), increased heat loss from the ocean (Screen and Simmonds 2010a, b), the water vapour and cloud radiative feedbacks (Sedlar et al. 2011), and the small heat capacity of the shallow stably stratified boundary layer (Esau and Zilitinkevich 2010). It should be noted that there is no general consensus on the relative importance of various factors responsible for the Arctic amplification and sea ice decline. According to model experiments, the amplification occurs also in a world without sea ice (Alexeev et al. 2005).

\section{Local Effects of Sea Ice Decline}

In this section, we address the local effects of sea ice decline over the Arctic Ocean and its marginal seas, whereas remote effects felt in sub-Arctic and mid-latitudes are reviewed in Sect. 4. Some of the essential local and remote effects are summarized in Fig. 3 and Table 1. 


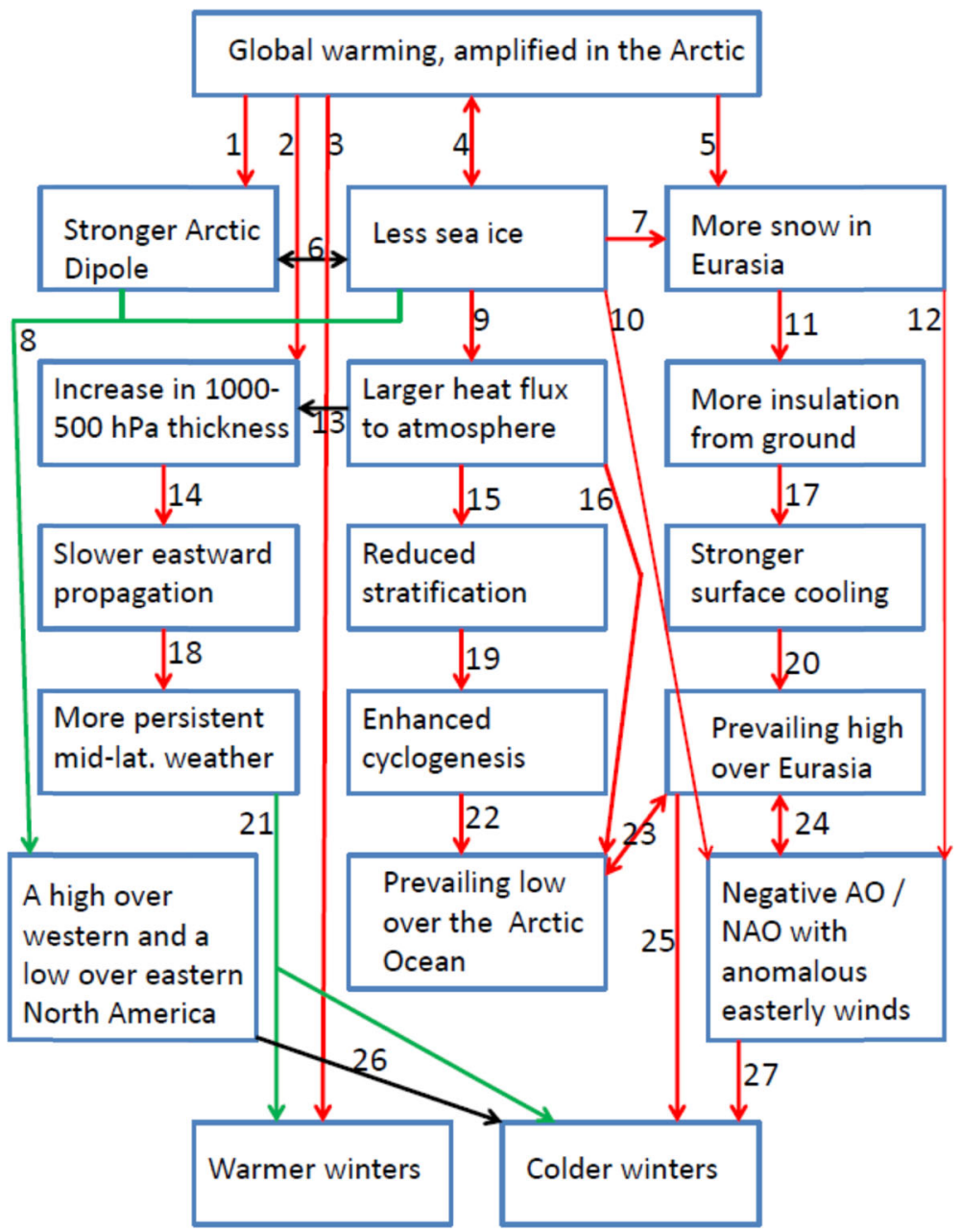

Fig. 3 Simplified schematic illustration of interactions in the climate system, with a focus on the effects of summer/autumn changes in the cryosphere on winter weather in mid-latitudes. The studies suggesting the mechanisms 1-27 are listed in Table 1. Different colours are used to help to distinguish between different lines

\subsection{Studies Based on Observations and Reanalyses}

Several observational studies have addressed the effects of leads and polynyas on the Arctic atmosphere, but these studies have mostly focused on small- and mesoscale process understanding (e.g., Andreas et al. 1979; Pinto et al. 2003). With a climatological perspective, Serrezze et al. (2009) and Screen and Simmonds (2010a, b) have shown the recent anomalously large open water areas in September have resulted in a strong transfer of heat from the ocean mixed layer to the atmosphere, causing a large increase in air temperature. In recent years, positive air temperature anomalies have been particularly strong in October, a month after the seasonal sea ice minimum (Stroeve et al. 2012). For winter and spring, Tetzlaff et al. (2013) found that as much as 70-90\% of the 2-m air 
Table 1 Suggested effects of cryospheric changes on weather and climate. The numbers in the first column refer to Fig. 3

\begin{tabular}{|c|c|}
\hline No. & References \\
\hline 1 & Overland and Wang (2010), Blüthgen et al. (2012) \\
\hline 2 & Francis et al. (2009), Overland et al. (2010; 2011b, 2012) \\
\hline 3 & $\begin{array}{l}\text { Christensen et al. (2007), Serreze et al. (2009; 2011), Deser } \\
\text { et al. (2010), Petoukhov and Semenov (2010), Overland } \\
\text { et al. (2011a); Yang and Christensen (2012), Stroeve et al. } \\
\text { (2012), Peings and Magnusdottir (2013) }\end{array}$ \\
\hline
\end{tabular}

4 Effects of climate warming on sea ice decline: e.g., Meier et al. (2011), Polyakov et al. (2012) and Stroeve et al. (2012). Effects of sea ice decline on climate warming: e.g., Serreze and Barry (2011), Kumar et al. (2010), Screen et al. $(2012,2013 a)$

5 Cohen et al. (2012a) for autumn, but not supported by Brown and Derksen (2013). Bulygina et al. (2009), Borzenkova and Shmakin (2012), Callaghan et al. (2011), and Park et al. (2012) suggested an increase in winter

6 Overland and Wang (2010), Blüthgen et al. (2012)

7 Cohen et al. (2012a), Ghatak et al. (2012), Park et al. (2012), Callaghan et al. (2011)

Level of certainty ${ }^{\mathrm{a}}$

Low/intermediate

High

High

High

Intermediate for winter, probably not valid for autumn

\section{Low/intermediate}

Intermediate for winter, probably not valid for autumn

8 Francis et al. (2009); Strey et al. (2010); Balmaseda et al. (2010)

9 e.g., Rinke et al. (2006), Lüpkes et al. (2008a,b), Francis et al. (2009), Serrezze et al. (2009), Screen and Simmonds (2010a,b), Overland and Wang (2010), Stroeve et al. (2011), Jaiser et al. (2012), Strey et al. (2012), Outten and Esau (2012)

10 Alexander et al. (2004), Magnusdottir et al. (2004), Deser et al. (2004; 2010), Cohen et al. (2012a), Seierstad and Bader (2009), Petoukhov and Semenov (2010), Liu et al. (2012), Outten and Esau (2012), Magnusdottir et al. (2004), Sokolova et al. (2007), Honda et al. (2009), Strey et al. (2010), Yang and Christensen (2012), Rinke et al. (2013), Peings and Magnusdottir (2013), Tang et al. (2013), Grassi et al. (2013), Screen et al. (2013b)

11 Cohen et al. (2012a), Tang et al. (2013)

12 Cohen et al. (2007, 2012a), Hardiman et al. (2008), Allen and Zender (2011), Peings et al. (2012)

13 Francis et al. (2009), Overland and Wang (2010), Overland et al. (2010; 2011b, 2012), Rinke et al. (2013), Screen et al. (2013b)

14 Farncis and Vavrus (2012), Overland et al. (2012), Peings and Magnusdottir (2013), but questioned by Barnes (2013) and Screen and Simmonds (2013)

15 Francis et al. (2009), Deser et al. (2010), Overland and Wang (2010), Stroeve et al. (2011), Kay et al. (2011), Jaiser et al. (2012), Rinke et al. (2013), Screen et al. (2013b)

16 Alexander et al. (2004), Singarayer et al. (2006), Higgins and Cassano (2009), Strey et al. (2010), Blüthgen et al. (2012), Jaiser et al. (2012), Cassano et al. (2013), Screen et al. (2013a)

Low/intermediate

High

Intermediate $^{\mathrm{b}}$

High

Intermediate $^{\mathrm{b}}$

High

Low

High

Intermediate; location of the low and timing of its occurrence vary

17 Cohen et al. (2012a), Park et al. (2012), Tang et al. (2013)

High 
Table 1 continued

\begin{tabular}{|c|c|c|}
\hline No. & References & Level of certainty ${ }^{a}$ \\
\hline 18 & Francis and Vavrus (2012) & $\operatorname{High}^{\mathrm{c}}$ \\
\hline 19 & Jaiser et al. (2012) & $\operatorname{High}^{\mathrm{c}}$ \\
\hline 20 & $\begin{array}{l}\text { Allen and Zender (2011), Cohen et al. (2012a), Tang et al. } \\
\text { (2013), Peings et al. (2012) }\end{array}$ & Intermediate/high \\
\hline 21 & Francis and Vavrus (2012) & High \\
\hline 22 & Higgins and Cassano (2009) & High \\
\hline 23 & Cohen et al. (2012a), Tang et al. (2013) & Intermediate \\
\hline 24 & $\begin{array}{l}\text { Cohen et al. (2007, 2012a), Hardiman et al. (2008), Allen } \\
\text { and Zender (2011), Peings et al. (2012) }\end{array}$ & Intermediate $^{\mathrm{b}}$ \\
\hline 25 & $\begin{array}{l}\text { Cohen et al. (2007, 2012a), Hardiman et al. (2008), Allen } \\
\text { and Zender (2011), Outten and Esau (2012), Peings et al. } \\
\text { (2012), Liu et al. (2012), Rinke et al. (2013) }\end{array}$ & High \\
\hline 26 & Francis et al. (2009), Strey et al. (2010) & High \\
\hline 27 & Basically all papers listed in 10 and 12 above & $\operatorname{High}^{\mathrm{d}}$ \\
\hline
\end{tabular}

a Subjective estimate by the author of this review

b The effects resemble the negative phase of AO/NAO, with negative index values, but the vertical structure of the response is often baroclinic, i.e. different from the equivalent barotropic structure of AO/NAO

c The mechanisms are well known, but it is unclear how often they dominate over other factors

d The relationship is sensitive to the mid-latitude region

temperature variance over the Arctic Ocean was explained by the distribution of surface temperature along the air mass trajectory. The distribution was mostly controlled by SIC.

The increase in heat flux from the ocean to the atmosphere has resulted in a reduction in vertical static stability (Francis et al. 2009; Overland and Wang 2010; Stroeve et al. 2011; Jaiser et al. 2012). Francis et al. (2009) also related the reduction in summer sea ice to increased total-column water vapour content in the NCEP/NCAR reanalysis in the following winter. On the basis of the same reanalysis, addressing the period 2002/2008, Overland and Wang (2010) detected widespread regions in the Arctic during late autumn having surface air temperature anomalies greater than $3{ }^{\circ} \mathrm{C}$, and temperature anomalies above $850 \mathrm{hPa}$ of $1{ }^{\circ} \mathrm{C}$. These temperature anomalies contributed to an increase in the $1,000-500 \mathrm{hPa}$ thickness field in every year with reduced sea ice cover. The increase in the Arctic results in a decrease in the north-south gradient of the 1000-500 hPa layer thickness, which, according to the thermal wind law, further results in a reduction in the midtropospheric zonal wind speed (Fig. 4).

Jaiser et al. (2012) analysed the response of the Arctic atmosphere to SIC from 1989 to 2010 on the basis of the European Center for Medium-Range Weather Forecast (ECMWF) ERA-Interim reanalysis and Hadley Centre's sea ice dataset (HadISST1). They showed that during periods of a low SIC, stronger heat release to the atmosphere reduces the vertical static stability, which makes the atmosphere more liable to baroclinic instability. It consequently modulates the nonlinear interactions between baroclinic wave energy fluxes on time scales of $2.5-6 \mathrm{~d}$.

\subsection{Model Experiments Addressing Processes and Recent Climate}

Effects of Arctic leads and polynyas on the atmospheric boundary layer (ABL) have been addressed in numerous experiments applying numerical weather prediction (NWP) models, 
Fig. 4 Schematic illustration on the effect of Arctic amplification of climate warming on the zonal wind speed according to the thermal wind relation. When the north-south temperature gradient is large, the 1,000-500 $\mathrm{hPa}$ layer thickness has a large southward gradient, which results in a zonal wind speed strongly increasing with height (upper panel). When the Arctic warms more than midlatitudes, the thickness gradient and the upper-level zonal winds weaken (lower panel)

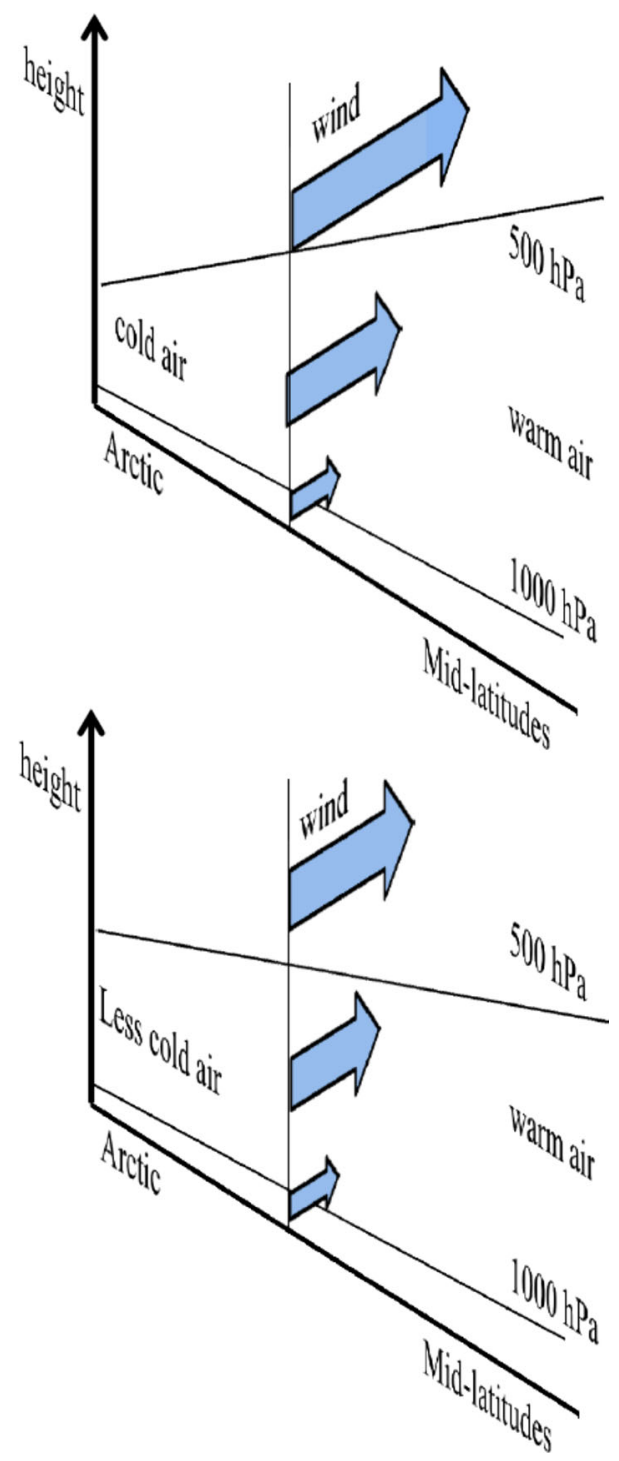

large-eddy simulation models, and process models for ABL dynamics (e.g., Ledley 1988; Vihma 1995; Esau 2007; Lüpkes et al. 2008a, b, 2012; Ebner et al. 2011). These studies have yielded a better understanding of various processes: the magnitude of turbulent fluxes of sensible and latent heat, the effects on air temperature and humidity, formation of sea smoke, the rise of a heat plume under variable background stratification, and the recapture of part of the heat by sea ice downwind of the lead/polynya, as well as on the effect of thin ice on the lead/polynya surface. Realistic parameterizations of these processes are important in climate model experiments addressing the effects of reduced sea ice cover. If the sea ice decline is mostly due to a reduction in sea ice extent, instead of concentration, the effects are fortunately easier to present in climate models, as the heat and moisture 
fluxes originate from larger areas of open water, without so much subgrid-scale variation in the surface fluxes.

Most of the model experiments focusing on local ABL processes have not explicitly addressed the impact of changes in sea ice cover. Lüpkes et al. (2008a), however, simulated the near-surface air temperatures over the Arctic Ocean for various SICs, geostrophic wind speeds, and flow times over the ocean with a broken ice cover. They found that a $1 \%$ decrease in SIC may have up to $3.5{ }^{\circ} \mathrm{C}$ warming effect on the $10-\mathrm{m}$ air temperature. This represents the maximum sensitivity, and is only reached in mid-winter under clear-sky conditions when the air mass flows for at least 3 days over the ocean. The sensitivity decreases for larger reductions in sea cover: in the same conditions, a decrease from 100 to $90 \%$ ice concentration would cause a $24{ }^{\circ} \mathrm{C}$ warming effect (from -45 to $-21{ }^{\circ} \mathrm{C}$ ), hence less than 10 times the increase caused by the $1 \%$ sea ice decrease. The simulations by Lüpkes et al. (2008a) were idealized, but experiments by Valkonen et al. (2008), validated against buoy observations over the Antarctic sea ice in winter, suggested an approximately similar sensitivity.

Next, we focus on large-scale model experiments. Alexander et al. (2004) applied the Community Climate Model version 3 (CCM3) to simulate the atmospheric response to the low sea ice extent of 1995 (Fig. 1). Focusing on the cold season, November through March, Alexander et al. (2004) found over areas of anomalous open water an increase in surface heat fluxes, near-surface warming, enhanced evaporation and precipitation, and a lower sea-level pressure. Bhatt et al. (2008) applied the same model to study the response to 1995 sea ice conditions. Although they focused on the April-October period, the results were fairly similar to those of Alexander et al. (2004), larger surface fluxes and higher near-surface air temperatures in the area of open water.

Numerous recent modelling studies have addressed the atmospheric response to the September 2007 sea ice minimum. Balmaseda et al. (2010) ran several experiments using the ECMWF operational global seasonal forecasting system. For their 2007/2008 experiment using observed sea surface temperature (SST) fields, they found a significant impact on atmospheric circulation with anomalous high pressure over the central Arctic in summer. Their study suggested that the atmospheric response to sea ice extent strongly depends on the mean state of the atmosphere, which can be characterized, among others, by the Arctic Oscillation (AO) index. Strey et al. (2010) and Porter et al. (2012) applied the Weather Research and Forecast (WRF) model to study the atmospheric response during autumn and early winter for the sea ice minimum of 2007. As a reference Strey et al. (2010) looked at the corresponding response for the sea ice conditions of 1984, which represented the median September ice extent for the 1979-2008 satellite record. The surface fluxes of heat and moisture and the 2-m air temperature were increased in autumn 2007. As measured by the difference in $2 \mathrm{~m}$ temperatures between 2007 and 1984, the maximum response to sea ice decline, averaged over the area north of $70^{\circ} \mathrm{N}$, occurred over a long time period: from 10 September to 15 November. Porter et al. (2012) had 1996 as a reference year, representing a summer with a high sea ice extent. The local response to less sea ice in 2007 was largest in October and November, dominated by increased turbulent fluxes of sensible and latent heat from the open sea. These resulted in warmer and moister air as well as increases in the ABL height, cloud cover, and precipitation.

Also, Kay et al. (2011) modelled the atmospheric response to the sea ice minimum of 2007. They applied the Community Atmosphere Model Version 4 (CAM4), and carried out short-term observationally constrained forecasts and longer term experiments in which the atmosphere freely evolved. Kay et al. (2011) found that in July the near-surface temperature and humidity were little affected by sea ice loss in the same month. This is no 
surprise, because during the melting season the surface temperatures of the open water and sea ice are close to each other, typically within $2 \mathrm{~K}$. For September they found near-surface decreases in stability and humidity increases aloft over the areas of anomalous open water. In the experiments of Blüthgen et al. (2012), an atmospheric general circulation model was driven with the observed 2007 sea surface temperatures and SICs. The simulations resulted in increased heating of the ocean in summer and increased heat loss from the ocean to the atmosphere in autumn, yielding higher near-surface air temperatures over northern Siberia and the Eastern Arctic Ocean. A low anomaly in sea-level pressure was present over the Eastern Arctic. These anomalies were present in almost all of the 40 realizations of the model experiment. The low over the Eastern Arctic reinforced the Arctic Dipole pattern. Via this effect, the sea ice export through the Fram Strait was enhanced, which acted as a positive feedback to the low sea ice extent. Cassano et al. (2013) applied the Community Atmospheric Model version 3 (CAM3) in two 30-year simulations; one with climatological sea ice extent for late 1900s and another with sea ice extent from 2007. The latter yielded the strongest atmospheric response in autumn and winter, with lower sea level and tropospheric pressures over much of the Arctic as well as enhanced evaporation and sensible heat loss from the Chukchi and East Siberian Seas, but lower surface fluxes form the Barents Sea.

Next, we address studies that focus on a longer time frame than a single year. Rinke et al. (2006) forced the regional climate model HIRHAM over an Arctic domain with two different sea ice and SST boundary conditions but the same lateral boundary conditions. Areas of higher SSTs and reduced sea ice thickness and concentration were associated with stronger upward heat fluxes and higher 2-m air temperatures. Rinke et al. (2013) applied the coupled regional climate model HIRHAM-NAOSIM in a six-member ensemble of simulations for the period 1949-2008. The local responses to negative Arctic sea ice anomalies included increased heat and moisture fluxes, decreased static stability, and increased lower tropospheric moisture. Furthermore, the model generated changes in baroclinicity, qualitatively as in Fig. 4. Applying two atmospheric general circulation models for the period 1979-2009, Screen et al. (2013b) obtained qualitatively similar results. The response of clouds to variations in sea ice extent over the Laptev Sea was studied by Barton and Veron (2012). Experiments applying the Polar version of WRF were run for eight Septembers and Octobers, representing anomalously low and high sea ice extent. Barton and Veron (2012) found that a low sea ice extent results in more clouds with larger liquid water paths. Low sea ice extent also results in an increased cloud longwave radiative forcing at the sea surface, but only in October. In September the cloud cover was thick enough to emit almost as a black body independent of the sea ice cover.

The importance of sea ice decline on Arctic warming was put in a broader perspective by Kumar et al. (2010) and Screen et al. (2012, 2013a). According to the model experiments by Kumar et al. (2010), the anomalous sea ice conditions during 2007 accounted for virtually all of the estimated Arctic amplification in warming of the lowermost $1000 \mathrm{~m}$ of the atmosphere over the Arctic Ocean during that year. The signal was strongest in September through December. On the basis of both reanalyses and model experiments, Screen et al. (2012) concluded that local changes in SIC and SST explain a major part of the observed near-surface warming. On the other hand, the Arctic warming at higher altitudes (upwards of $700 \mathrm{hPa}$ level) was mostly due to increased SST further south, which has heated the air masses advected to the Arctic from lower latitudes. According to Screen et al. (2012), an increase in the direct radiative forcing has contributed to Arctic tropospheric warming mostly in summer. Screen et al. (2013a) carried out large ensembles of simulations applying two atmospheric GCMs: CAM3 and the UK-Australian Unified 
Model. On the basis of the model results they separated the forced atmospheric response to historical Arctic sea ice loss (1979-2009) from atmospheric internal variability. In both models, the local responses included statistically significant near-surface atmospheric warming and precipitation increase in autumn and winter. Screen et al. (2013a) further diagnosed a decrease in the sea-level pressure in both models but, compared with atmospheric internal variability, the signal attributable to sea ice decrease was weaker than in the case of air temperature and precipitation increases.

As a summary, high-resolution models can provide detailed information on convection over leads, polynyas, and the open ocean. Such models are fairly well validated against observations, although various challenges remain (Vihma et al. 2013). Studies applying climate and NWP models have yielded qualitatively similar results on the local atmospheric response to sea ice loss, including larger turbulent fluxes of sensible and latent heat, and consequent increases in the ABL height, air temperature, specific humidity, relative humidity, cloud cover, and precipitation, as well as a decrease in stratification. Due to the limited availability of observations, however, these model results are not well validated but, as several model experiments have yielded similar results and the physical processes are well understood, we can be rather confident on the responses in a qualitative level (Table 1). Considering the mean sea-level pressure, model experiments have yielded scattered results; most experiments, however, suggest that the response to sea ice los will be a pressure decrease with a low over the Arctic Ocean in autumn and winter.

\subsection{Model Experiments Addressing the Future}

Model results on the future climate over the Arctic Ocean are reviewed in the IPCC Fourth Assessment Report (Christensen et al. 2007) and in the Arctic Monitoring and Assessment Program (AMAP) report on snow, water, ice and permafrost in the Arctic (Overland et al. 2011a). These reports have, however, not often explicitly referred to the relationship between the sea ice decline and climate change. According to both Christensen et al. (2007) and Overland et al. (2011a), the largest warming over the Arctic Ocean is predicted for winter and the smallest for summer and, due to the sea ice melt, the predicted warming is larger over the ocean than land, except in summer. In summer the sea ice melt forces the local near-surface air temperatures close to the melting point (Vihma et al. 2008). Hence, the seasonal amplitude of the predicted temperature change is much larger over the ocean than over land. Both Christensen et al. (2007) and Overland et al. (2011a) consider that the large warming over the central Arctic Ocean is dominated by the warming in winter/ autumn associated with the reduced sea ice. According to Overland et al. (2011a), local maxima in winter warming by the period $2070-2090$ will be $6-7{ }^{\circ} \mathrm{C}$ (based on the A1B emission scenario) in the areas that have lost sea ice. According to Christensen et al. (2007), the relative increase in precipitation will be largest over the Arctic Ocean: $30-40 \%$ by the end of the century, and according to Overland et al. (2011a) the maximum absolute increase in marine Arctic precipitation will occur in the Barents and Kara Seas.

Among the first studies explicitly focusing on the future effects of Arctic sea ice decline was Singarayer et al. (2006), who applied the Hadley Centre Atmospheric Model 3 (HadAM3). Their results suggested a large increase in near-surface air temperature, mostly in winter, which was due to increased heat flux from the new ice-free parts of the ocean. The sea-level pressure was reduced in most of the circumpolar Arctic, and also evaporation was projected to increase, resulting in a consequent increase in precipitation. Higgins and Cassano (2009) carried out CAM3 experiments with the sea ice cover prescribed on the basis of climate model projections (ensemble of A1B scenario runs) for the period 
2080-2099. As a reference they used the period of 1980-1999. The sea ice decline was associated with a large decrease in sea-level pressure, which in turn was related to an increased frequency of strong low-pressure systems in the central Arctic. Also precipitation increased over large regions in the Arctic. Higgins and Cassano (2009) interpretation of the results was that the autumn synoptic patterns extended into the winter (Strey et al. (2010) interpreted their results similarly). The same model was applied by Deser et al. (2010) with a focus on the same period: 2080-2099. Over the Arctic Ocean they found large increases in air temperature and precipitation in winter.

As a summary, climate model experiments suggest that the local atmospheric response to sea ice loss will be a continuation and amplification of the response that has occurred so far. An exception is that, according to my knowledge, no climate model experiments have suggested an increase in mean sea-level pressure over the central Arctic by the end of the century.

\section{Remote Effects of Sea Ice Decline}

\subsection{Studies Based on Observations and Reanalyses}

By regulating the heat exchange between the ocean and atmosphere, the Arctic sea ice decline is expected to affect atmospheric circulation and weather patterns, not only in the marine Arctic, but also further south. The simplest mechanism of a remote effect is that positive temperature anomalies are generated over areas where sea ice has melted, and atmospheric circulation spreads the anomalies horizontally to influence adjacent regions (Serreze et al. 2009, 2011; Stroeve et al. 2012). On the basis of NCEP/NCAR reanalysis, Serreze et al. (2011) showed that during northerly winds air temperatures in northern midlatitudes $\left(60-70^{\circ} \mathrm{N}\right)$ were warmer in the period $2000-2009$ than in the reference period 1979-2009. The warming was largest, $0.5-2{ }^{\circ} \mathrm{C}$, in autumn and winter in the European, Bering Strait, and eastern Canadian sectors.

The remote effects of sea ice decline on the large-scale pressure and wind patterns are more complex. Recent important findings are related to

(a) the time scale of the atmospheric response to sea ice decline in various seasons,

(b) the relative importance of barotropic and baroclinic components of the atmospheric response,

(c) the resemblance of the atmospheric response to negative $\mathrm{AO}$, and

(d) the atmospheric response in summer (in (a) to (c) the studies have mostly focused on autumn and winter).

Related above all to (a), Francis et al. (2009) analysed satellite data on sea ice extent and in situ atmospheric observations and concluded that variations in summer sea ice conditions are associated with anomalies in atmospheric large-scale circulation in the following autumn and winter. They found statistically significant anomalies in air temperature, sea-level pressure, and precipitation over extensive regions in the Northern Hemisphere. For example, the detrended time series showed reduced sea-level pressure over eastern North America and increased sea-level pressure over western North America. Francis et al. (2009) suggested that the main mechanisms for this lagged effect are related to deepening of the Atmospheric Boundary Layer (ABL), warming and destabilization of the lower troposphere, increased cloudiness, and decrease in the poleward gradient in the thickness of the atmospheric layer between 500 and $1,000 \mathrm{hPa}$ pressure levels (topic 
(b) above). The decreased gradient weakens the polar jet stream (Fig. 4). On the basis of ERA-Interim reanalysis, Tang et al. (2013) showed, however, that the winter circulation changes and cold extremes in the period of 1979-2011 were more strongly associated with sea ice reduction in winter than summer. The sea ice loss favoured a high-pressure anomaly over the subarctic, which in part results from fewer cyclones owing to a weakened meridional temperature gradient over the sea ice zone. According to Tang et al. (2013), the weakening is caused by a southward shift of the strongest gradient, due to earlier autumn snow fall and cooling of the Eurasian continent (Sect. 5). Accordingly, the sea ice loss favours the occurrence of cold winter extremes in continental mid-latitudes.

Related to (b), similar to Francis et al. (2009), Overland and Wang (2010) emphasized the importance of the increase of the 1,000-500 hPa layer thickness over the Arctic (Sect. 3.1) and the consequent decrease in the north-south gradient in the thickness field. Overland and Wang (2010) interpreted that gradients in this thickness field represent the baroclinic contribution to the flow from loss of sea ice. In addition, atmospheric circulation has a barotropic component, which is more variable. Overland and Wang (2010) concluded that the sea ice decline has a direct connection to increased thickness fields in every year, but not necessarily to the sea-level pressure fields. Overland and Wang (2010) illustrated the baroclinic contribution by comparing the years 2002-2008 with diminished late autumn sea ice cover against the climatology of years 1968-1996. In the years with less sea ice, late autumn easterly winds near the surface north of Alaska and Canada were strengthened by $1.4 \mathrm{~m} \mathrm{~s}^{-1}$ (40\%) relative to climatology, whereas in the upper troposphere westerly winds were strengthened by $3 \mathrm{~m} \mathrm{~s}^{-1}$. Jaiser et al. (2012) suggested, however, that the remote impact of Arctic sea ice loss on the large-scale circulation during winter exhibits a barotropic structure with similar pressure anomaly patterns at the surface and in the mid-troposphere. The different results of Overland and Wang (2010) and Jaiser et al. (2012) may be related to differences in their focus on direct and indirect responses. According to Deser et al. (2004), the direct response to surface thermal anomaly is localized to the vicinity of the anomaly (SST or sea ice) and exhibits a baroclinic structure in the vertical, whereas the indirect response is equivalent barotropic even up to the tropopause, and dominates the total geopotential height response. The analyses of Jaiser et al. (2012) suggested that the pressure anomalies are connected to pronounced planetary wave train changes notably over the North Pacific.

Overland et al. (2011b) paid attention to the pattern of warm Arctic with surrounding cold continents in winter 2009-2010 and December 2010. The typical Polar vortex was replaced by high geopotential heights over the central Arctic and low heights over midlatitudes that resulted in anomalous easterly winds and record snow and low temperatures. The relationships of large-scale circulation and cyclone tracks were addressed by Inoue et al. (2012), who applied the NCEP-NCAR reanalysis and the University of Melbourne cyclone tracking algorithm. In years with little ice in the Barents Sea, an anticyclonic anomaly prevailed along the Siberian coast. The situation was associated with warm advection over the Barents Sea and cold advection over eastern Siberia. Warm conditions in the Barents Sea were related to a weaker sea surface temperature gradient and lower baroclinicity, preventing cyclones from travelling eastward, favouring an anticyclonic anomaly over the Siberian coast.

Related to (c), on the basis of satellite data on sea ice and terrestrial snow areas and reanalysis data on atmospheric variables, Liu et al. (2012) showed that the decrease in autumn Arctic sea ice area is linked to changes in the winter large-scale circulation that have some resemblance to the negative phase of the winter AO, but the interannual variability is different. Furthermore, the changes linked to the sea ice decline include 
broader meridional meanders in mid-latitudes. Liu et al. (2012) further pointed out that, in addition to effects on winter mean statistics, the autumnal sea ice decline also increases the frequency of occurrence of strong weather events, such as snow storms and cold-air outbreaks. Also the observations by Honda et al. (2009) demonstrated that significant cold anomalies over the Far East in early winter and zonally elongated cold anomalies from Europe to Far East in late winter are associated with the decrease in Arctic sea ice cover in the preceding summer and autumn. The mechanisms are discussed in Sect. 4.2.

A resemblance of atmospheric response to negative $\mathrm{AO}$ was also detected by Outten and Esau (2012). On the basis of ERA-Interim reanalysis, they identified cooling trends of wintertime near-surface air temperature along a band that extends across mid-latitude Eurasia. They explained the cooling as a result of an extreme warming around the Kara Sea, which was strongly related to sea ice decline (correlation coefficient of -0.83 between SIC and 2-m air temperature). Outten and Esau (2012) interpreted that the weakened north-south temperature gradient has caused a decrease in wintertime westerly winds over mid-latitude Eurasia, resulting in lower temperatures (Fig. 3). Comparing the Kara Sea and the Eurasian region where the winter cooling has been strongest $\left(70-95^{\circ} \mathrm{E}, 48-59^{\circ} \mathrm{N}\right)$, the correlation coefficient between the meridional temperature gradient and the Eurasian zonal wind was as high as 0.77 .

Next, we consider studies on topic (d): links between the Arctic SIC and mid-latitude summer weather. Using the NCEP-NCAR reanalysis and rain station observations, Wu et al. (2009) detected a statistical relationship between spring Arctic SIC and Chinese summer rainfall in 1968-2005. A decreased (increased) spring SIC was associated with increased (decreased) summer rainfall in northeast China and central China between the Yangtze River and the Yellow River; and decreased (increased) rainfall in south China. The links were associated with a wave train structure in $500 \mathrm{hPa}$ height anomalies, originating from northern Europe and extending to northeast China (Fig. 5). In a continuation study, Wu et al. (2013) applied the NCEP-NCAR and JRA-25 reanalyses for the period 1979-2010 and found that the winter SIC anomalies west/southwest of Greenland were significantly correlated with the following summer atmospheric circulation over the Eurasian mid- and high latitudes. The summer 500-hPa height anomalies were affected by SIC and SST anomalies; a low SIC was associated with a low summer mean 500-hPa height over the Hudson Bay and western Europe. The anomalies dynamically corresponded to the Eurasian pattern of $850-\mathrm{hPa}$ wind variability and influenced summer rainfall over northern Eurasia. The results based on the reanalysis were supported by experiments applying an atmospheric general circulation model ECHAM5, forced by observed SST and SIC fields.

As a summary, studies based on observations and reanalyses suggest that the Arctic sea ice decline has had several remote effects; the most evident ones related to the fact that cold-air outbreaks from the Arctic are, on average, not as cold as they used to be. Probably, more important, but simultaneously more difficult to attribute as causal effects of sea ice decline, are the remote effects on the large-scale pressure field and geostrophic wind over mid-latitudes. Reduction in westerly winds has been suggested by several studies, and the effect is physically understandable via the baroclinic mechanism (Fig. 4), although the detection of the effect is made difficult by the often dominating barotropic component of the sea-level pressure field. It is also unclear to what extent the atmospheric patterns observed in winter represent lagged responses to the sea ice decline in previous summerautumn and represent the fast responses to the smaller sea ice decline in winter. Effects of sea ice decline on summer weather have mostly been observed in Eurasia. 


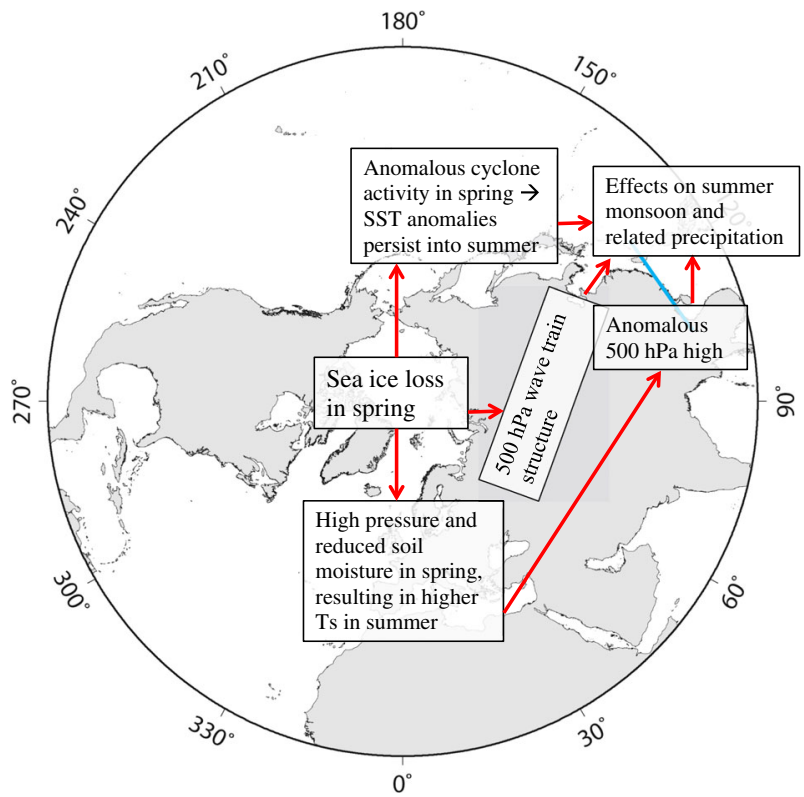

Fig. 5 Proposed links between springtime Arctic sea ice decline and East Asian summer monsoon. The blue line indicates the approximate location of the Meiyu front. For more information on the link via Eurasia, see Zhao et al. (2004) and Wu et al. (2009), and on the link via Pacific, see Guo et al. (2013)

\subsection{Model Experiments Addressing Processes and Recent Climate}

Recent studies have addressed (a) the effects on the AO and NAO, (b) occurrence of cold winters, (c) the remote atmospheric response to summer/autumn 2007 sea ice minimum, (d) remote effects of regional sea ice decline in the Barents and Kara Seas, and (e) summer precipitation in Europe, the Mediterranean, and East Asia. Again, except of (e), the focus has been on effects in autumn and winter.

Related to (a), Magnusdottir et al. (2004) applied CCM3 with prescribed SST and sea ice anomalies in the North Atlantic sector. Even with exaggerated SST amplitude, the atmospheric response to the SST anomaly was quite weak compared with the observed positive trend in the NAO from 1950s to 1990s. Compared with SST, the anomalies in sea ice extent had stronger effects on atmospheric circulation. While increase in SST supported the positive trend in the NAO, the decrease in sea ice extend supported a decrease in the NAO. Sokolova et al. (2007) made experiments using a coupled atmosphere-ocean model (ECHO-G). Starting from the present-day conditions, they ran a 500-year experiment (with the present-day greenhouse gas forcing), and then analysed the weather patterns during 14 years: those with the seven largest and seven smallest ice extents. In general, with little sea ice, the zonal wind decreased north of $40^{\circ} \mathrm{N}$ and increased southward. Between 60 and $70^{\circ} \mathrm{N}$, however, reduced sea ice was in some regions (Scandinavia, western Russia, parts of Greenland and Alaska) associated with increased zonal winds. The pattern with high (low) sea ice, resembled the positive (negative) AO pattern.

In the coupled regional climate model experiments by Rinke et al. (2013) (see Sect. 3.2), atmospheric large-scale circulation in a winter following a low September sea ice extent included more meridional flow patterns, resembling a negative AO pattern, and 
supporting cold winters in northern Eurasia. The simulated atmospheric response was, however, highly sensitive to the position and strength of the regional sea ice anomalies and to the analysed time period. The Beaufort Sea was the key region to control the atmospheric large-scale response to sea ice decline. Peings and Magnusdottir (2013) applied the Community Atmospheric Model version 5 (CAM5) to simulate the wintertime circulation response to sea ice conditions observed in 2007-2012. The sea ice decline favoured low land surface temperatures in late winter over mid-latitudes, above all over Asia. Anomalous large Rossby waves penetrated into the stratosphere in February and weakened the stratospheric polar vortex, which further generated negative $\mathrm{AO}$ anomalies. The response in the troposphere was strongest over the North Pacific, suggesting the importance of sea ice anomalies in the Sea of Okhotsk. Also the model experiments of Screen et al. (2013b) suggested that the early winter (November-December) atmospheric circulation response resembles the negative phase of the NAO, although so weak that it is often masked by inherent variability.

Considering (b), the occurrence of cold winters, Yang and Christensen (2012) analysed the model results of the Climate Model Intercomparison Project phase 5 (CMIP5) to study the relationship of European winter climate and the Arctic sea ice reduction. In the historical period of 1956-2005, cold winters in Europe were rarely associated with a reduced sea ice cover in the Barents and Kara Seas: 12 out of 13 CMIP5 models simulated less than $30 \%$ of cold winter months to occur simultaneously with a significantly (more than $10 \%$ ) reduced sea ice cover. For the results of Yang and Christensen (2012) on future occurrence of cold winters, see Sect. 4.3.

Considering (c), remote effects of the sea ice minimum in summer/autumn 2007 have been modelled by Balmaseda et al. (2010), Strey et al. (2010), Orsolini et al. (2012), and Blüthgen et al. (2012). Contrary to many results that a cold winter follows a summer/ autumn with a low sea ice cover, winter 2007-2008 was not anomalously cold in the northern mid-latitudes in general (Blüthgen et al. 2012). For example, in Finland the winter (December-February) was the warmest during the observational record since early 1900s (Niinimäki 2008). Over the circumpolar north, strong warm anomalies existed during autumn, and these were reproduced by the models. Orsolini et al. (2012) ran an ensemble of hindcast simulations using the ECMWF seasonal forecast model. They found robust near-surface warm anomalies up to $10 \mathrm{~K}$ mostly north of $60^{\circ} \mathrm{N}$, over a wide sector from 30 to $270^{\circ} \mathrm{E}$ in October and November. In December weaker warm anomalies extended throughout the troposphere, mostly generated by advection of warm air masses on the western sides of the American and Eurasian continents. The experiments by Strey et al. (2010), described in Sect. 3.2, suggested that the remote responses in the late autumn and early winter atmospheric circulation throughout the troposphere were characterized by a quasi-barotropic ridge/trough signal in North America. These circulation patterns generated anomalous cold-air advection, which further affected the air temperature and precipitation over eastern North America and the North Atlantic. Strey et al. (2010) further associated the advective temperature anomalies with surface flux anomalies over remote regions such as the Great Lakes and the Gulf Stream. The atmospheric response was different in summer: the experiments of Balmaseda et al. (2010) resulted in an anomalous high pressure over the Arctic associated with low-pressure centres over western Europe and northwest North America.

Topic (d), remote effects of prescribed regional sea ice decline in the Barents and Kara Seas, has been studied by Honda et al. (2009), Petoukhov and Semenov (2010), and Grassi et al. (2013). Honda et al. (2009) applied a Japanese atmospheric general circulation model, which supported the observations reported in Sect. 4.1. In early winter a stationary 
Rossby wave was generated due to anomalous turbulent heat fluxes, which resulted from the reduced sea ice cover. The Rossby wave tended to amplify the Siberian high, generating colder conditions in the Far East due to increased advection of Arctic/Siberian air masses. With reduced sea ice cover, the observed anomalously low temperatures over Eurasia in late winter were successfully simulated, and associated with the negative phase of NAO due to a weaker Icelandic low.

Petoukhov and Semenov (2010) applied the ECHAM5 global atmospheric model to study the atmospheric response to prescribed decreases of wintertime SIC in the Barents and Kara seas. Their results suggested that a small decrease in ice concentration, from 100 to $80 \%$, resulted in an anomalous cyclonic circulation over the Arctic Ocean, whereas a larger decrease from 80 to $40 \%$ resulted in an anomalous anticyclonic circulation. The latter case was associated with anomalous easterly winds over the surrounding continents. This generated a winter cooling of about $-1.5{ }^{\circ} \mathrm{C}$ in large parts of Eurasia and North America. The probability of cold winter extremes increased by more than three times over large areas. If the winter SIC in the Barents and Kara Seas dropped down to $1 \%$, however, the circulation over the Arctic Ocean turned to cyclonic again, generating winter warming over Eurasia and the USA. Petoukhov and Semenov (2010) showed that the results were supported by a conceptual model, which suggested that the nonlinear atmospheric response was mostly due to an interaction of convection over the surface heat source in the Barents and Kara Seas and the baroclinic effect due to modified temperature gradients in the vicinity of the heated region. Petoukhov and Semenov (2010) also noted the role of spatial variations in the cross-isobaric angle of the ABL wind, which was affected by differences in surface roughness and stratification between the open ocean and sea ice. Their study is unique in recognizing this effect.

Grassi et al. (2013) carried out two sets of CAM3 simulations, prescribing different values of SIC (50 and $20 \%$ ) on the Barents-Kara Seas. The global CAM3 results provided boundary conditions for a regional model over the central Europe and the Mediterranean. The simulations yielded a large-scale atmospheric circulation response to sea ice reduction, resembling the negative phase of $\mathrm{AO}$ in winter, with an increase in the occurrence and intensity of extreme cold events, over continental Europe, and extreme precipitation events, over all the Mediterranean basin. In particular, Grassi et al. (2013) detected an increased risk of winter flooding on southern Italy, Greece and Iberian peninsula.

Topic (e), the relationship between the Arctic sea ice decline and European summer precipitation, has been recently addressed by Screen (2013). According to his data analysis, the observed wet (dry) summer months in central and northern Europe typically occurred when the $300-\mathrm{hPa}$ jet stream was displaced to the south (north) of its average position. Model experiments applying the U.K. Met Office Unified Model yielded similar results. A prescribed sea ice loss resulted in a southward displacement of the $300-\mathrm{hPa}$ jet and increased rain fall in central and northern Europe, except northern Scandinavia. Screen (2013) estimated that the sea ice decline contributes to approximately one-third of the observed increase in the central and northern European summer precipitation during 1979-2009. Screen (2013) proposed the following mechanism for the effect (Fig. 6): Sea ice loss in the Sea of Okhotsk in winter and spring results in increased cyclogenesis, which strengthens the North Pacific storm track. The prevailing low over the North Pacific, together with sea ice loss in the Hudson Bay and the Labrador Sea, generate a stationary wave train, which results in a prevailing low over the Northeast Atlantic and British Isles in May-June. The mechanism links the results of Screen (2013) to earlier studies. The effect of sea ice loss in the Hudson Bay and the Labrador Sea was suggested by Wu et al. (2013) (Sect. 4.1). Already Honda et al. $(1996,1999)$ suggested that sea ice anomalies in the Sea 


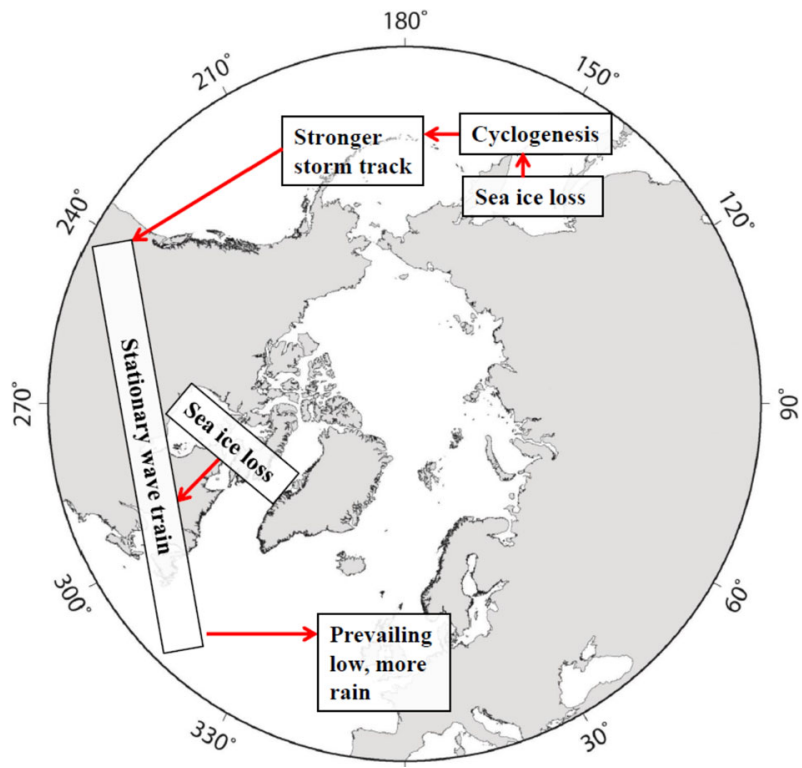

Fig. 6 Links between sea ice loss (in the Sea of Okhotsk, Hudson Bay, and Labrador Sea) and European summer precipitation. The mechanisms have been suggested by Screen (2013), Mesquita et al. (2011), and Wu et al. (2013)

of Okhotsk generate a stationary wave train response with far reaching downstream effects. On the basis of NCEP/NCAR reanalysis and ECHAM5 model experiments, Mesquita et al. (2011) found that sea ice loss in the Sea of Okhotsk strengthens the North Pacific storm track. Bhatt et al. (2008) suggested, however, a weakened storm track and a higher sealevel pressure over the North Pacific as a response to the low sea ice cover of summer 1995 (see also Sect. 3.2).

Recent studies have also addressed the effects of Arctic sea ice decline on the summer monsoon in southern China. Already Zhao et al. (2004) suggested, on the basis of data analyses and model experiments, that sea ice loss in spring enhances summer monsoon rainfall in southeastern China. Negative anomalies in spring sea ice extent tend to generate a high sea-level pressure over Europe, and via land surface processes and stationary wave dynamics, illustrated in Fig. 5, an anomalous $500 \mathrm{hPa}$ high is generated over east Asia in summer. It favours the invasion of cold-air masses into southern China and preventing the East Asian summer monsoon from advancing northward. The Meiyu front is therefore intensified and stays over southeastern China, yielding a lot of rain fall there (Zhao et al. 2004). On the basis of observations and coupled atmosphere-ocean and atmosphere-only model experiments Guo et al. (2013) suggested a different link from spring Arctic sea ice extent and East Asian summer monsoon. The spring sea ice anomalies cause anomalous surface heat fluxes resulting in atmospheric circulation anomalies, which, in turn, cause SST anomalies in the North Pacific. The SST anomalies can persist into summer and then impact the summer monsoon circulation and precipitation over East Asia (Guo et al. 2013). Reduced spring Arctic sea ice leads to an enhancement of summer rainfall in northeast China and in the belt including the Indochinese Peninsula, South China Sea, Philippines, and the region east of Guam. 
Concurrently, the rainfall over the Meiyu front (and two fronts further north) significantly decreases.

The differences between the model results are noteworthy: Zhao et al. (2004) obtained an increase in rainfall over the Meiyu front, whereas Guo et al. (2013) obtained a decrease. On the basis of observations and reanalysis (Sect. 4.1), Wu et al. (2009) associated a decrease in Arctic sea ice cover with a decrease in summer rainfall in southern China, which supports Guo et al. (2013). With respect to the mechanisms, the results of Zhao et al. (2004) and Wu et al. (2009) had, however, common features, both suggesting a wave train structure over Eurasia.

As a summary, several modelling studies suggest that the Arctic sea ice decline favours large-scale pressure patterns resembling the negative phase of NAO (with negative index values), although the vertical structure of the pressure patterns may often be baroclinic, instead of the equivalent barotropic structure of the NAO (Woollings 2008). Sea ice conditions in the Barents and Kara Seas have received a lot of attention, and model experiments with prescribed sea ice cover in these areas have suggested that a sea ice decline tends to generate colder winters in Europe and the Far East. According to CMIP5 model results, however, during 1956-2005 the occurrence of cold winters has rarely been associated with reduced sea ice cover in the Barents and Kara Seas. The atmospheric response for the September 2007 sea ice minimum included long-lasting warm weather in autumn, but in winter cold anomalies prevailed over North America and warm ones over Europe. Although many remote effects on mid-latitude winter weather effects have been suggested, the ensemble of model simulations by Screen et al. (2013a) did not show clear remote effects at mid-latitudes, suggesting that these may be partially or wholly masked by atmospheric internal variability. The probable effects of Arctic and sub-Arctic sea ice decline on European summer precipitation have been demonstrated, and different mechanisms linking the Southeast Asian summer monsoon with Arctic spring sea ice decline have been suggested, yielding different results and indicating a need for further studies.

\subsection{Model Experiments Addressing the Future}

Seierstad and Bader (2009) applied the atmospheric general circulation model ECHAM5, forced by the present and a projected future seasonal cycle of Arctic sea ice. In the experiment with projected sea ice concentrations for the period 2081-2099, without other changes in the model forcing, significant reductions in storminess were found during winter in both mid-latitudes and towards the Arctic. The reduction was largest in March and also related to the negative phase of NAO (Seierstad and Bader 2009).

According to the model experiments by Deser et al. (2010), described in Sect. 3.3, during the period 2080-2099 the projected Arctic sea ice decline will generate strong responses in air temperature and precipitation over the adjacent continents. It is noteworthy that the results of Deser et al. (2010) do not suggest that the sea ice decline causes decrease in winter air temperatures over northern high-latitude continents. Instead, the atmospheric response is seen as increasing temperatures, particularly in winter in regions where a strong low-level temperature inversion prevails in the present climate. When the surface heating destroys the shallow inversion layer, which has a small heat capacity, the temperature increase is larger than it would be in a case when the same surface heating is distributed in a thick well-mixed layer. The effect detected by Deser et al. (2010) on the large-scale circulation has a baroclinic vertical structure over the Arctic in November-December, but it changes to an equivalent barotropic structure in January-March. Only in February the structure resembles the negative NAO. Deser et al. (2010) also analysed the model results 
where only the sea ice cover was changed according to 2080-2099 projections and compared with fully coupled model results (including, among others, the increases in $\mathrm{CO}_{2}$ concentration and SST). They concluded that Arctic sea ice loss accounts for most of the seasonal, spatial, and vertical structure of the high-latitude warming response to greenhouse gas forcing at the end of this century.

According to Yang and Christensen (2012; their Table 2), CMIP5 models clearly suggest that the situation described in Sect. 4.2 (cold mid-latitude winters rarely associated with reduced sea ice) is changing: in the period of 2006-2100, in the 13 model mean, $76 \%$ of cold winter months coincided with cases of sea ice reduction by more than $10 \%$ in the Barents and Kara Seas (numbers reported are for the medium-low RCP4.5 emission scenario (Thomson et al. 2011). Yang and Christensen (2012) concluded that while a warming trend will prevail in Europe, episodes of cold months will remain common during the first half of this century: the model results suggest that the probability for the occurrence of cold winters in Europe will decrease to $59 \%$ of that during the reference period of 1971-2000. In the second half of the century, the corresponding probability is expected to further drop down to $31 \%$. Yang and Christensen (2012) concluded that the pattern of a negative AO with an anomalously cold Europe and warm Arctic is typical for the cold events of the future.

In addition to processes in the present climate (Sect. 4.2), Peings and Magnusdottir (2013) simulated the atmospheric response to the sea ice anomalies projected for 2080-2099. Negative AO anomalies were produced in the troposphere in winter. These mostly resulted from a large warming of the Arctic lower troposphere, with little impact from the stratosphere. The westerly flow became weaker (due to the baroclinic effect) and mid-latitude meanders slightly increased. However, the widespread tropospheric warming, driven by the sea ice decline, prevented the occurrence of cold episodes in mid-latitudes, except in February when the negative AO had a dominating effect. Considering February, however, it should be noted that the greenhouse gas forcing was kept in the present-day level in all model experiments of Peings and Magnusdottir (2013).

As a summary, the results of Petoukhov and Semenov (2010), Deser et al. (2010), Yang and Christensen (2012), and Peings and Magnusdottir (2013) all suggest that a sea ice decline much larger than we have experienced so far no longer favours the occurrence of cold winters in northern mid-latitudes. Although Overland et al. (2011a) do not explicitly write about the remote effects of sea ice decline, it is noteworthy that in their selected subset of climate models the results for the period 2070-2090 suggest warmer winters over all sea and land areas in northern mid- and high latitudes.

\section{Effects Not Fully Attributable to Sea Ice Decline}

The Arctic sea ice decline is by no means the only factor affecting the weather and climate in mid-latitudes. The effects of tropospheric large-scale circulation patterns are strong and have received a lot of attention (e.g., Thompson and Wallace 1998; Larkin and Harrison 2005; Liu and Alexander 2007; Moore and Renfrew 2012). In addition, the climate change in the Arctic and sub-Arctic has generated other mechanisms that tend to affect midlatitude weather and climate. Attention has been paid to mechanisms related to the Arctic amplification of climate warming and, in spite of it, the possible increase in Siberian snow cover. 


\subsection{Arctic Amplification of Climate Warming}

The Arctic amplification is partly, but not solely, due to sea ice decline (Alexeev et al. 2005; Serreze and Barry 2011). As an example of their differences, sea ice area in the Arctic Ocean and Canadian Archipelago have not decreased in winter (Cavalieri and Parkinson 2012), although winter air temperatures have risen more in the Arctic than in mid-latitudes (Walsh et al. 2011). The reduction in the meridional temperature gradient has the potential to change the atmospheric circulation in mid-latitudes. This was demonstrated by Francis and Vavrus (2012), who analysed daily fields of the 500 and 1,000 hPa pressure levels in 1970-2010, and identified two important changes: the zonal winds have weakened (because the thermal wind has weakened, Fig. 4) and the amplitude of Rossby waves has increased. According to Francis and Vavrus (2012), both these changes have contributed in slowing down the eastward propagation of upper-level waves, which tends to cause weather patterns in mid-latitudes to be more persistent (Fig. 3). The increase in the wave amplitude in mid-troposphere has also been observed by Overland et al. (2012), and Zhang et al. (2012) have detected a pronounced intensification of high-latitude anticyclone activity since early 2000s. Also the model results of Peings and Magnusdottir (2013) support the idea that the sea ice decline leads to an increase in the meridional meander of mid-latitude planetary waves. The statistical significance of this signal was low in model experiments for the present climate, but higher in experiments forced by sea ice conditions projected for 2090.

The results by Fransis and Vavrus (2012) were, however, questioned by Barnes (2013) and Screen and Simmonds (2013), who showed that the calculated trends in the planetary wave amplitude and phase speed depend on the metric used. Investigating three reanalyses, Barnes (2013) did not find any significant decrease in planetary-scale wave phase speeds, except in October-December, but this trend was sensitive to the analysis parameters. Neither the frequency of blocking occurrence exhibited significant increase in any season further supporting the lack of trends in wave speed and meridional extent. Furthermore, according to Francis and Vavrus (2012), $500 \mathrm{hPa}$ winds in October-December have robustly decreased over the North Atlantic from 1980 to 2011, but according to Barnes (2013) there has been no significant decreases in wind speeds from 1995 to 2011. Screen and Simmonds (2013) used two definitions of planetary wave amplitude; one is a measure of north-south meandering and another one is a measure of the intensity of atmospheric ridges and troughs at $45^{\circ} \mathrm{N}$. Statistically significant changes in either metric only occurred in April to June, and only for certain wavelengths and longitudinal sectors. Screen and Simmonds (2013) concluded that possible connections between the Arctic amplification and planetary waves are sensitive to how waves are conceptualized. Furthermore, there are signs of decrease in high-latitude blocking events over the North Atlantic during the last 30-40 years (Croci-Maspoli et al. 2007; Davini et al. 2012; Barnes 2013), although the results may be sensitive to the analysis methodology.

In summer, the sea ice decline does not have much effect on the air temperature. Hence, if there has been an increasing tendency for high-amplitude patterns, it is probably related to warming of high-latitude land in spring and early summer. Francis and Vavrus (2012) suggest that enhanced 500-hPa ridging over the eastern North Atlantic is consistent with more persistent high surface pressure over western Europe, which according to Jaeger and Seneviratne (2011) has probably contributed to the recent record heat waves in Europe.

As a summary, we may expect that the reduction in the meridional temperature gradient and the 1,000-500 hPa thickness gradient reduces the zonal winds. This may further increase the amplitude of planetary waves and slow down their eastward propagation. It is, 
however, not clear if there have been any significant changes in the wave amplitude and phase speed so far. Even if not, the increasing persistency of mid-latitude weather is a potential future scenario that deserves a lot of research.

\subsection{Changes in Terrestrial Snow Pack}

A widespread winter cooling trend has been observed over northern Eurasia and eastern North America since approximately 1988. According to Cohen et al. (2012a) this trend is probably not due to internal variability alone, but due to an increase in Eurasian snow cover in autumn. They estimated that the rate of increase in October has been on average $1.5 \times 10^{6} \mathrm{~km}^{2}$ per decade. Due to the insulating effect and higher albedo of the snow pack, an anomalously high pressure has been formed over northern Eurasia, tending to generate a negative AO index and anomalous easterly winds in Eurasian mid-latitudes (Fig. 3). Cohen et al. (2012a) suggested that the increase in autumn snow fall is caused by (a) a general increase in atmospheric moisture content due to a warming climate, and (b) the decrease in Arctic sea ice cover, which is supposed to enhance evaporation in autumn (Fig. 3). The model experiments of Ghatak et al. (2012) supported particularly the latter.

Brown and Derksen (2013), however, carried out detailed comparisons of four independent sources of snow cover data, and concluded that Eurasian October snow cover extent has not increased but instead decreased over 1982-2011. Brown and Derksen (2013) found that the increasing trend (reported by Cohen et al. 2012a) is only present in a single satellite-based data set, being an artificial one due to an improved snow mapping over the years (Helfrich et al. 2007). Brown and Derksen (2013) noted, however, that there is evidence of increasing precipitation and winter snow accumulation over large regions of Russia (Bulygina et al. 2009; Borzenkova and Shmakin 2012; Callaghan et al. 2011; Park et al. 2012), which is consistent with increased air moisture over the Arctic Ocean and Eurasia (Serreze et al. 2012; Cohen et al. 2012a). Hence, the insulation and albedo mechanism suggested by Cohen et al. (2012a) may well be relevant, but during winter instead of autumn (the albedo effect is naturally less important in winter).

In addition to the influence of Eurasian autumn snow cover on mid-latitude winter weather, several studies have suggested that the Eurasian snow cover may also influence the Arctic. This takes place by wave trains propagating downstream over the North Pacific and vertically into the stratosphere, with a lagged impact in the Arctic (Cohen et al. 2007; Orsolini and Kvamstø 2009; Allen and Zender 2011). In addition, Peings et al. (2012) modelled the relationship of the Siberian snow cover and winter AO. A positive snow mass anomaly imposed from October to March had a strong effect on the extratropical winter circulation, resembling the negative phase of AO. Also here the mechanism involves the wave propagation into the stratosphere, and a good representation of stratosphere in the model was essential to capture it correctly.

Seager et al. (2010) investigated the reasons for the anomalously large snowfall in winter 2009-2010 in northwestern Europe and the eastern parts of the United States. They discovered strong effects of the El Niño and NAO, but did not refer to any link with the Arctic sea ice decline. On the contrary, Park et al. (2012) found strong links. They examined the relationships of Arctic sea ice extent in September, terrestrial snow depth, and precipitation, during the period of 1979-2006. Their analyses of satellite data on sea ice extent and snow depth, simulated by a land surface model, suggested that an anomalously large snow depth over northeastern Siberia during autumn and winter was significantly correlated with the declining September Arctic sea ice extent. According to Park 
et al. (2012) the thick snow pack has resulted in cooling and increasing precipitation. On the contrary, over most of the circumpolar north, snow depths have decreased in winter. Due to the sea ice decline, temperatures have increased over most of North America, which has dominated over the increased snow precipitation, and the snow depth has decreased.

As a summary, it seems that the autumn snow cover extent has not increased in Eurasia. Instead, winter snow depths have increased over large parts of Russia, but decreased over most of the circumpolar north. Different trends over different regions and seasons are related to the competing effects of increasing air temperature and winter precipitation. Increasing winter snow cover in Russia may favour formation of a high-pressure centre, yielding easterly winds in Europe.

\section{Reliability of the Methods Applied}

Most of the studies cited are based on at least some of the following: remote sensing data on sea ice extent and concentration; reanalyses of atmospheric pressure, wind, air temperature, air humidity, and precipitation; and experiments applying climate and Numerical Weather Prediction (NWP) models. These all include uncertainties, but it is not always straightforward to estimate how crucial the uncertainties have been for the conclusions presented in the papers cited.

\subsection{Accuracy of Observations}

Prior to satellite passive microwave observations, information available on Arctic sea ice concentration, area, and extent was very inaccurate, but most of the studies cited have addressed the period after 1979 with the availability of microwave data. Related to uncertainties in the processing algorithm applied, however, the Arctic sea ice extent may still have an uncertainty of up to $1 \times 10^{6} \mathrm{~km}^{2}$ (Kattsov et al. 2010). For various other error sources and challenges, see Cavalieri et al. (1999). In addition to uncertainties in instantaneous sea ice conditions, the generation of a long-term, consistent time series is challenging because of the different sensors onboard satellites in different years. Each of the sensors may differ in their measurement wavelengths, fields of view, angles of incidence, ascending node times, and calibrations (Cavalieri and Parkinson 2012). The recent decline in the Arctic sea ice extent and area has, however, been so dramatic that the observational uncertainties cannot change the overall picture.

Estimates on the heat flux from the partly ice-covered ocean to the atmosphere are, however, very sensitive to the processing algorithm applied for the passive microwave data. In the Antarctic sea zone in winter, Valkonen et al. (2008) showed that even in short simulations of 2 days the modelled 2-m air temperature may differ by up to $13 \mathrm{~K}$ depending on the source of SIC data. Such numbers are reached during cold-air outbreaks when the fetch over broken sea ice cover is large enough (of the order of $1,000 \mathrm{~km}$ ). Hence, if the SIC is underestimated (overestimated), the effects on weather may be strongly overestimated (underestimated), at least locally.

As a summary, observations available are accurate enough to convincingly document the dramatic decrease in the Arctic sea ice extent and thickness during the recent decades, but challenges remain in observations on changes in the extent and thickness of terrestrial snow cover (Sect. 5.2). Furthermore, inaccuracy of SIC observations generates inaccuracies in model experiments addressing the past. 


\subsection{Accuracy of Reanalyses}

Atmospheric reanalyses include serious errors, especially in the ABL. On the basis of evaluation against independent observations, Jakobson et al. (2012) demonstrated that during spring and summer over the Arctic Ocean, all reanalyses have large errors in the vertical profiles of air temperature as well as specific and relative humidity. Even ERAInterim, which had the best overall performance in this study, had a warm bias of up to $2{ }^{\circ} \mathrm{C}$ in the lowermost $400 \mathrm{~m}$ layer (for errors in air humidity, see below). These results were in line with Lüpkes et al. (2010), who compared ERA-Interim against R/V Polarstern rawinsonde soundings, which were assimilated in the reanalysis. Also Serreze et al. (2012) used Arctic radiosonde sounding data to evaluate the MERRA, CFSR and ERA-Interim reanalyses. During cold seasons all these reanalyses had warm and moist biases below the $850 \mathrm{hPa}$ level and did not capture observed low-level humidity and temperature inversions. All reanalyses included in the study of Jakobson et al. (2012), (ERA-Interim, NCEP-CFSR, NCEP-DOE, JCDAS, and MERRA), strongly underestimated the wind shear in the lowermost $100 \mathrm{~m}$ layer, which, together with the warm and moist biases, suggested too much mixing in the ABL.

The mean sea-level pressure field over the Arctic fortunately seems to be better captured by reanalyses. Already the previous-generation reanalyses, ERA-40 and NCEP-NCAR agreed well in the timing and location of cyclones over the Arctic (Bromwich et al. 2007). Polar lows and other mesoscale features are naturally much more challenging. The success in synoptic-scale pressure field is partly due to the buoy network maintained by the International Arctic Buoy Programme. Inoue et al. (2009), however, pointed out that with a decreasing sea ice cover in summer and autumn, larger gaps appear without buoy observations on sea-level pressure, which tends to decrease the accuracy of reanalyses and weather forecasts for the Arctic.

Little is known about the factors responsible for the Arctic climate variability in the mid-troposphere. In spite of the strong near-surface warming, in the period of 1998-2011 radiosonde sounding data and four reanalyses show a cooling trend in the Arctic-mean $500 \mathrm{hPa}$ temperature in autumn (Chung et al. 2013).

Several observational and modelling studies have directly or indirectly suggested that the sea ice decline results in increased evaporation from the Arctic Ocean (Singarayer et al. 2006; Higgins and Cassano 2009; Deser et al. 2010; Ghatak et al. 2010; Cohen et al. 2012a; Liu et al. 2012; Barton and Veron 2012; Tang et al. 2013). There is, however, not much direct evidence on increased evaporation. Atmospheric models are known to have major problems in moisture variables in the Arctic. For example, (a) in the NCEP-NCAR and NCEP-DOE reanalyses the annual net precipitation is about $60 \%$ lower than the water vapour flux convergence (Cullather et al. 2000), (b) the ERA-Interim reanalysis has a large moist bias of $0.3-0.5 \mathrm{~g} \mathrm{~kg}^{-1}$ throughout the lowermost $1 \mathrm{~km}$ over the Arctic sea ice (Lüpkes et al. 2010; Jakobson et al. 2012), (c) the largest differences between reanalyses are related to depiction of clouds (Bromwich et al. 2007), and (d) the specific humidity and cloudiness based on NCEP-NCAR reanalysis are so inaccurate that they cannot be recommended for forcing of sea ice models (Makshtas et al. 2007).

Due to the above-mentioned problems, Boisvert et al. (2012) developed an alternative approach to estimate evaporation in the Arctic (North Water Polynya) applying wind speed based on the ERA-Interim reanalysis and air humidity and surface temperature based on the Atmospheric Infrared Sounder (AIRS) onboard NASA's Earth Observing System (EOS) Aqua satellite. Calculations for the circumpolar Arctic for the period of 2003-2010 suggested an increasing trend of evaporation from the Arctic Ocean in March through 
September (Boisvert et al. 2013), which is in line with other studies. For December through February, however, a significant decreasing trend was found for the Kara/Barents Seas, East Greenland Sea and Baffin Bay. From the point of view of evaporation, the observed increase in air specific humidity compensates for the increase in surface temperature (Boisvert et al. 2013). An increase in the poleward transport of heat and moisture (Graversen et al. 2008a, b, 2011; Yang et al. 2010) is a potential reason for the observed increase in air specific humidity in winter.

As a summary, atmospheric reanalyses have errors in the surface, ABL, cloud, and precipitation variables. Hence, conclusions on the Arctic climate change should not be made on the basis of a single reanalysis, but several reanalyses as well as in situ and satellite observations should be utilized.

\subsection{Reliability of Climate Models}

Even more than reanalyses, climate models suffer from uncertainties in the Arctic. This is illustrated by the large scatter that models have in projections for the twenty-first century (Overland et al. 2011a). Tjernström et al. (2005) showed that six regional climate models (RCM) had serious errors in the turbulent fluxes of heat and moisture when compared against the observations made in the Surface Heat Budget of the Arctic Ocean Experiment (known as SHEBA). Their correlation with observed fluxes was insignificant, and they accumulated over a year to values an order of magnitude larger than observed. On the basis of analogous comparisons, Tjernström et al. (2008) concluded that, even in cases when the model cloud cover qualitatively matched the observed cover, regional climate models typically had a negative bias of some tens of $\mathrm{W} \mathrm{m}^{-2}$ for both longwave and shortwave downward radiation. The errors in radiative fluxes and the sensible heat flux seem to partly compensate for each other. Furthermore, Kay et al. (2011) reported that CCSM3 has generated unrealistic cloud feedbacks in the Arctic (until they made corrections). The effect of model uncertainties in polar regions is well demonstrated by Hawkins and Sutton (2009; their Fig. 6): for the projected surface air temperature close to the end of the twentyfirst century, the globally most important source of uncertainty is that of greenhouse gas emissions scenarios, but for the Arctic the uncertainty of the climate models is even larger. Considering modelling of sea ice, a lot of improvements have recently been made in climate models (Vihma et al. 2013), but the snow cover on top of sea ice is usually still represented by a single layer only. This makes models liable to errors when the solar radiation is large (Cheng et al. 2008).

In climate models, problems are not restricted to subgrid-scale processes, but the models include deficiencies also in the summertime synoptic activity in the Arctic (Christensen et al. 2007), which reduces confidence in the projected spatial patterns of climate change. Compared with global models, RCMs show more warming along the sea ice margin, possibly due to a better horizontal resolution, allowing a better description of the mesoscale weather systems and air-sea fluxes associated with the ice edge (Christensen et al. 2007). Over most of the central Arctic and Siberia, however, the warming tends to be lower in RCM simulations, particularly in summer (by up to $2{ }^{\circ} \mathrm{C}$ ).

In general, climate models (at least those included in the IPCC 4th Assesment Report) have been too conservative in simulating the Arctic sea ice decline (Stroeve et al. 2007), but the models have reproduced the decreasing trend. Unfortunately the linkages between the snow cover and NAO/AO have not been successfully reproduced in climate models (Allen and Zender 2011). According to Hardiman et al. (2008), Smith et al. (2011), Peings et al. (2012), and Cohen et al. (2012a) there are at least the following reasons for this: 
(a) models underestimate inter-annual variability in snow cover, (b) models have not reproduced the observed winter cooling over large parts of Eurasia, (c) models have problems in the gravity wave response and upward vertical propagation, and (d) due to linear interference, models with different climatological mean stationary waves get different responses to surface forcing. According to Peings et al. (2012), a good representation of the stratosphere was crucial to correctly capture the effect of Siberian autumnal snow cover on the tropospheric large-scale circulation in winter.

The sensitivity of climate model results is demonstrated by the fact that Screen et al. (2012) and Peings and Magnusdottir (2013) applied two versions of the same model: CAM3 and CAM5. Screen et al. (2012) identified a weak strengthening of the stratospheric polar vortex while Peings and Magnusdottir (2013) found a substantial weakening of the polar vortex and then a downward propagation of this signal to the surface. This major discrepancy in results was probably due to numerous small differences between the model versions.

Uncertainties may also arise from the modelling strategy with respect to sea surface temperatures (SST). In model experiments with the ocean and sea ice prescribed, the atmospheric response to sea ice decline may be sensitive to the treatment of SST (Balmaseda et al. 2010). In the summer monsoon study by Guo et al. (2013) (Sect. 4.2), the essential role of SST was demonstrated by the fact that a coupled atmosphere-ocean model was needed to reproduce the observed linkage between the spring sea ice and summer monsoon. Graversen et al. (2008a) found that the Arctic warming at higher altitudes was mostly due to increased heat advection from lower latitudes. Screen et al. (2012) associated this with increased SST at lower latitudes, which has heated the air masses advected to the Arctic. Furthermore, Magnusdottir et al. (2004) noted that an increase in SST supported an increase in the NAO, whereas the decrease in sea ice extend supported a decrease in the NAO.

As a summary, climate models have problems, among others, in accurate enough simulation of the Arctic sea ice decline, stratosphere-troposphere interactions, atmosphereocean interaction, and $\mathrm{ABL}$ processes. Hence, conclusions on the Arctic-mid-latitude connections should not be made solely on the basis of results of a single climate model.

\section{Discussion}

The results based on observations, reanalyses, and model experiments suggest various changes in large-scale atmospheric circulation as a response to Arctic sea ice decline and changes in terrestrial snow cover. A pressure pattern essential for delivery of cold winter weather in North America is that found by Francis et al. (2009) and Strey et al. (2010): a low on the eastern side of the continent and a high over the western side, resulting in spreading of cold air over large parts of the continent (Fig. 3). Over Eurasia, a common feature suggested by several studies (Alexander et al. 2004; Cassano et al. 2006; Honda et al. 2009; Higgins and Cassano 2009; Strey et al. 2010; Blüthgen et al. 2012) is that in autumn and winter a low is generated over the Arctic ocean and a high over Siberia, as a response to the sea ice melt and/or increase in snow cover in Siberia. Such a pressure pattern may occur simultaneously with an Arctic Dipole pattern, and the model experiments by Blüthgen et al. (2012) indeed suggested that the sea ice decline in 2007 generated a low over the eastern Arctic, which reinforced the Arctic Dipole. Previously the Arctic Dipole has been regarded more as a driver than a consequence of the sea ice decline.

In Fig. 7a, I show an example of a monthly mean pressure field, where all the above suggested impacts of changes in sea ice and snow are realized: a high over northwestern America, a low over northeastern America (although the centre is over the Labrador Sea), a 

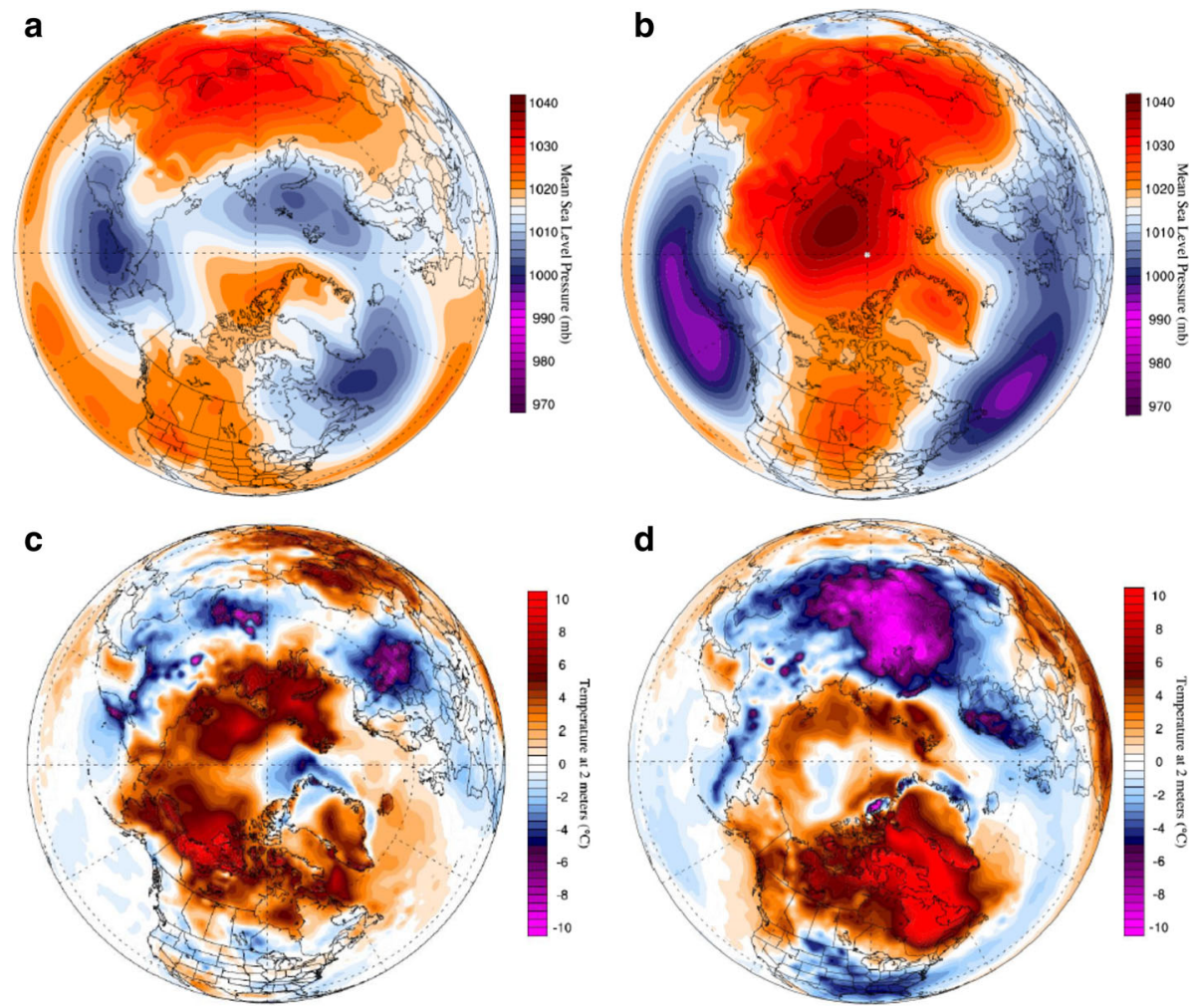

Fig. 7 Monthly mean fields of the sea-level pressure in (a) February 2006 and (b) February 2010, as well as 2-m air temperature anomaly with respect to the 1979-2012 mean in (c) February 2006 and (d) February 2010, based on the ERA-Interim reanalysis

high over Siberia, a low over the eastern Arctic, and a strong Dipole pattern. Such a situation occurred in February 2006, resulting in widespread cold anomalies in Eurasia and North America, while warm anomalies prevailed in the Arctic (Fig. 7c). In contrast to Fig. 7a, in Petoukhov and Semenov (2010) the reduction in SIC from 80 to $40 \%$ in the Barents and Kara Seas generated an increase in pressure over the central Arctic, including the Barents and Kara Seas. Such a situation occurred in February 2010 (Fig. 7b), when also the AO and NAO indices were extremely negative. Several studies have indeed suggested that the Arctic sea ice decline and increase in the Siberian snow cover both tend to generate a negative phase of the AO and NAO (Alexander et al. 2004; Magnusdottir et al. 2004; Deser et al. 2004, 2010; Sokolova et al. 2007; Cohen et al. 2007; Hardiman et al. 2008; Strey et al. 2010; Allen and Zender 2011; Liu et al. 2012; Yang and Christensen 2012; Peings et al. 2012; Screen et al. 2013b). Various studies give, however, different results for the strength and timing of the response of AO/NAO. If a strongly negative AO/NAO occurs in mid-winter, widespread cold anomalies down to $-10{ }^{\circ} \mathrm{C}$ in $2-\mathrm{m}$ air temperature may occur, as in February 2010 (Fig. 7d); such anomalies in a monthly mean are not only solely due to changes in heat advection, but also due to the strongly negative surface radiation budget under high-pressure conditions in winter (mechanisms 25 and 27 in Fig. 3). 
Accordingly, the suggested effects of Arctic sea ice decline include fairly different pressure patterns (Fig. 7), and in most monthly mean pressure fields during winters of the recent decade the above-mentioned patterns are less clearly present. One reason for this is that that sea ice decline directly affects only the baroclinic component of the pressure field, but the barotropic component is more variable (Overland and Wang 2010) and affected by numerous other factors. The role of the other factors is related to the result stressed by Balmaseda et al. (2010): the atmospheric response to sea ice decline strongly depends on the state of the atmosphere.

Considering remote effects of Arctic sea ice decline, large differences can be seen in the level of certainty that various authors have used in evaluating the causal relationships. One of the strongest conclusions was presented by Park et al. (2012): "diminishing Arctic sea ice has definitely increased the snow depth in the northernmost terrestrial Arctic during recent decades". According to Overland and Wang (2010) the increase in late summer open water area is "directly contributing to a modification of large scale atmospheric circulation patterns". According to Screen et al. (2013b), however, "the potential remote responses to Arctic sea ice change are currently hard to confirm and remain uncertain." Simulations by Screen et al. (2013b) did not show robust or widespread cooling in response to the rapid Arctic sea ice loss over the last 30 years. It is noteworthy that the effects of sea ice decline, and the related conclusions, may be sensitive to the study region. Sea ice loss in the vicinity of climatological storm tracks, as in the Sea of Okhotsk, Hudson Bay, and the Labrador Sea, seem to have a particularly large potential to affect the mid-latitude storm track (Kidson et al. 2011; Screen 2013).

The results presented in Sects. 3, 4 and 5 generate some hope for seasonal predictability of weather conditions in the Arctic and even in mid-latitudes. Among others, Strey et al. (2010) pointed out that the maximum response of 2-m air temperature to sea ice decline occurred over a long time period, from 10 September to 15 November. According to Orsolini et al. (2012), observations of sea ice conditions in late summer generate potential predictability for near-surface air temperatures over the Arctic in autumn, and also along the Pacific coast of Asia in December. In addition to sea ice, information on snow mass may also generate predictability, but for the spring. Peings et al. (2011) showed that using a snow analysis for initializing an atmospheric model on 1 March leads to a positive impact on a seasonal prediction of low-level temperatures. Also Liu et al. (2012) suggested that the relationships between sea ice cover, air temperatures, and snow fall can be of practical use in seasonal forecasting. We have to remember, however, that winter weather is very sensitive to small changes in the location and extent of pressure patterns. If a high in the central Eurasia is located somewhat more southwest of its usual position, European weather may be warm due to more southerly winds, as in Orsolini et al. (2012). Furthermore, one of the issues in predictability is the relative importance of the baroclinic and barotropic components of sea-level pressure variability. Dominance of the former would generate predictability, but in reality the latter is dominating.

It is noteworthy that the surface-induced modification of the synoptic and large-scale circulation is controlled by ABL processes. Petoukhov and Semenov (2010) paid attention to the interaction of convection and baroclinic effects, and the difference in the crossisobaric wind angle between sea ice and the open ocean. According to Deser et al. (2010) the twenty-first century temperature increase in winter will be largest in regions where a strong low-level temperature inversion prevails in the present climate, but will be destroyed in the future. Francis et al. (2009) suggested that the main mechanisms for the lagged effect of summer sea ice decline and autumn/winter large-scale circulation anomalies are partly related to deepening of the ABL and warming and destabilization of 
the lower troposphere, and Jaiser et al. (2012) stressed the importance of destabilization on the baroclinic instability. Bearing in mind the large errors in reanalyses and climate models in the ABL (Sect. 6), these findings call for more research on the Arctic ABL. Errors could be somewhat reduced by using better vertical resolution in climate models, but improved understanding on the ABL is also needed (Vihma et al. 2013).

\section{Conclusions}

It is evident that the decrease in Arctic sea ice area and extent in summer and autumn has affected the local weather and climate over the Arctic Ocean and its marginal seas. The air temperatures have increased, and the strength of the surface temperature inversion has decreased in autumn and early winter. Many authors also conclude that the sea ice decline has caused a local increase in evaporation, air moisture, cloud cover, and precipitation.

Considering remote effects, many recent studies suggest that the Arctic sea ice decline has affected and will further affect weather at northern mid-latitudes, but results scatter on the magnitude, timing, and spatial extent of these effects, as well as on the mechanisms behind them. Many studies suggest that the Arctic sea ice decline increases the probability for circulation patterns resembling the negative phase of $\mathrm{AO}$ and $\mathrm{NAO}$ in winter. A major challenge is, however, to understand if the recent negative NAO/AO values have been due to the sea ice decline or inherent decadal variability (e.g., Hurrell 1995).

Related to the negative AO/NAO, a pressure pattern with a low over the eastern Arctic and highs over Siberia and western North America would result in cold winter weather in large parts of Europe and North America. Such results originate from several studies applying different methods utilizing satellite data, reanalyses, and model experiments with various simulation strategies, but not all studies have yielded similar pressure patterns. The differences do not necessarily indicate model failures, but may reflect the fact that the atmospheric response to sea ice extent strongly depends on the state of the atmosphere (Balmaseda et al. 2010). A sea ice decline results in a local positive anomaly in air temperature, which creates a meander in the polar vortex flow, and the meander will have different downstream effects in different years (Overland et al. 2011b). Hence, the remote responses may be partially or wholly masked by atmospheric internal variability (Screen et al. 2013a). The winter weather in mid-latitudes and sub-Arctic is also affected by many other factors than the sea ice extent and terrestrial snow cover. In addition to the greenhouse forcing, the NAO and AO, these factors include the heat content of Atlantic and Pacific Oceans (Sutton and Dong 2012; Bond and Harrison 2000), the El Nino (Seager et al. 2010), stratospheric dynamics (Karpechko and Manzini 2012), volcanic aerosols (Robock 2000), and solar forcing (Ineson et al. 2011).

Hence, in any of the coming winters, it is by no means guaranteed that the large-scale dynamical processes that sea ice decline tends to generate will dominate over the other forcing factors. Our possibilities for seasonal forecasting of Northern Hemisphere mid- and high-latitude winter weather will probably not be strongly improved, neither by utilization of statistical methods nor by having an improved implementation of sea ice in forecast models. An exception may occur at certain regions where the Arctic-mid-latitude linkages seem particularly strong, such as the Kara Sea-western/central Siberia region (Outten and Esau 2012). Considering the circumpolar north, perspectives of forecasting October-December weather in the marine Arctic on the basis of September sea ice conditions seem, however, more promising. 
It is not clear for how many years the scenario of cold winters over Eurasian and North American continents will be realistic. There is a continuous competition between the global warming, amplified in the Arctic with the effects spreading southwards (Serreze et al. 2011), and the processes that the sea ice decline and increased snow cover tend to generate (Fig. 3). The model results of Petoukhov and Semenov (2010), Deser et al. (2010), Yang and Christensen (2012), and Peings and Magnusdottir (2013) all suggest that a sea ice decline much larger than we have experienced so far no more favours the occurrence of cold winters in northern mid-latitudes. Furthermore, climate model simulations for the end of the twenty-first century do not predict colder winters for northern high- and mid-latitude continents, but a strong warming instead (Christensen et al. 2007; Deser et al. 2010; Overland et al. 2011a; Yang and Christensen 2012). Deser et al. (2010) concluded that Arctic sea ice loss accounts for most of the seasonal, spatial, and vertical structure of the high-latitude warming response to greenhouse gas forcing at the end of this century.

Although most of the recent work has addressed the effects of sea ice decline on midlatitude weather in autumn and winter, there are indications that also the summer weather, in particular precipitation, is affected (Wu et al. 2009, 2013; Guo et al. 2013; Screen 2013).

As a summary, several linkages between the Arctic and mid-latitude climate have recently been proposed, but science on these linkages is still young, and the sample of years with a major sea ice loss is still small. To reduce uncertainties about causal links and validity of model results, we need better understanding and modelling capabilities related to (a) the Arctic sea ice cover and terrestrial snow cover, (b) interactions between the stratosphere and troposphere, (c) atmosphere-ocean exchange and ABL processes, and (d) the role of cyclones as a link in the interaction of the sea ice cover and atmospheric large-scale circulation. Finally, there is a need for more year-round observations on the Arctic sea ice and ABL, to more quantitatively understand the processes found essential in modifying the synoptic and large-scale circulation.

Acknowledgments I thank James Screen and three other reviewers for their constructive comments, as well as Mikko Alestalo and Alexey Karpechko for fruitful discussions. The work was supported by the Academy of Finland through the CACSI project (contract 259537). Figures 1 and 2 are courtesy of the National Snow and Ice Data Center, University of Colorado, Boulder, and Fig. 7 was prepared applying the Climate Reanalyzer, which is an initiative of the Climate Change Institute at the University of Maine.

Open Access This article is distributed under the terms of the Creative Commons Attribution License which permits any use, distribution, and reproduction in any medium, provided the original author(s) and the source are credited.

\section{References}

Alexander MA, Bhatt US, Walsh JE, Timlin MS, Miller JS, Scott JD (2004) The atmospheric response to realistic Arctic sea ice anomalies in an AGCM during winter. J Clim 17:890-905

Alexeev VA, Langen PL, Bates JR (2005) Polar amplification of surface warming on an aquaplanet in "ghost forcing" experiments without sea ice feedbacks. Clim Dyn 24:655-666

Allen RJ, Zender CS (2011) Forcing of the Arctic Oscillation by Eurasian snow cover. J Clim 24:6528-6539

Andreas EL, Paulson CA, Williams RM, Lindsay RW, Businger JA (1979) The turbulent heat flux from Arctic leads. Boundary Layer Meteorol 17:57-91

Bader J, Mesquita MDS, Hodges KI, Keenlyside N, Østerhus S, Miles M (2011) A review on Northern Hemisphere sea-ice, storminess and the North Atlantic Oscillation: observations and projected changes. Atmos Res 101:809-834 
Balmaseda MA, Ferranti L, Molteni F, Palmer TN (2010) Impact of 2007 and 2008 Arctic ice anomalies on the atmospheric circulation: implications for long-range predictions. Q J R Meteorol Soc 136:1655-1664

Barnes EA (2013) Revisiting the evidence linking Arctic amplification to extreme weather in midlatitudes. Geophys Res Lett 40:GRL50880

Barton NP, Veron DE (2012) Response of clouds and surface energy fluxes to changes in sea-ice cover over the Laptev Sea (Arctic Ocean). Clim Res 54:69-84

Belchansky GI, Douglas DC, Platonov NG (2004) Duration of the Arctic Sea ice melt season: regional and interannual variability, 1979-2001. J Clim 17:67-80. doi:10.1175/1520-0442(2004)017<0067: DOTASI $>2.0 . \mathrm{CO} ; 2$

Bhatt US, Alexander MA, Deser C et al (2008) The atmospheric response to realistic reduced summer Arctic sea ice anomalies. In Arctic sea ice decline: observations, projections, mechanisms, and implications. In: DeWeaver ET, Bitz CM, Tremblay LB (eds) Geophyical. Monogaph. Series, 180: 91-110. AGU: Washington, DC

Blunden J, Arndt DS (2012) State of the climate in 2011. Bull Am Meteorol Soc 93:S1-S264, Special supplement

Blüthgen J, Gerdes R, Werner M (2012) Atmospheric response to the extreme Arctic sea ice conditions in 2007. Geophys Res Lett 39:L02707. doi:10.1029/2011GL050486

Boisvert LN, Markus T, Parkinson CL, Vihma T (2012) Moisture fluxes derived from EOS aqua satellite data for the North Water Polynya over 2003-2009. J Geophys Res 117:D06119. doi:10.1029/ 2011JD016949

Boisvert LN, Markus T, Vihma T (2013) Moisture flux changes and trends for the entire Arctic in 2003-2011 derived from EOS Aqua data. Submitted to J Geophys Res

Bond NA, Harrison DE (2000) The Pacific Decadal Oscillation, air-sea interaction and central north Pacific winter atmospheric regimes. Geophys Res Lett 27:731-734

Borzenkova AB, Shmakin AB (2012) Changes in snow cover thickness and daily snowfall intensity affecting the highways cleaning expenses in Russian cities. Ice Snow 2:59-70 (in Russian with English summary and figure captions)

Bromwich DH, Fogt RL, Hodges KI, Walsh JE (2007) A tropospheric assessment of the ERA-40, NCEP, and JRA-25 global reanalyses in the polar regions. J Geophys Res 112:D10111. doi:10.1029/ 2006JD007859

Brown RD, Derksen C (2013) Is Eurasian October snow cover extent increasing? Environ Res Lett 8:024006

Brucker L, Markus T (2013) Arctic-scale assessment of satellite passive microwave derived snow depth on sea ice using operation icebridge airborne data. J Geophys Res (in press). doi:10.1002/jgrc.20228

Budikova D (2009) Role of Arctic sea ice in global atmospheric circulation: a review. Glob Planet Change 68:149-163

Bulygina ON, Razuvaev VN, Korshunova NN (2009) Changes in snow cover over Northern Eurasia in the last few decades. Environ Res Lett 4:L045026

Callaghan $\mathrm{T}$ et al (2011) The changing face of Arctic snow cover: a synthesis of observed and projected changes. Ambio 40:17-31

Cassano EN, Lynch AH, Cassano JJ, Koslow MR (2006) Classification of synoptic patterns in the western Arctic associated with extreme events at Barrow, Alaska, USA. Clim Res 30:83-97

Cassano EN, Cassano JJ, Higgins ME, Serreze MC (2013) Atmospheric impacts of an Arctic sea ice minimum as seen in the Community Atmosphere Model. Int J Climatol. doi:10.1002/joc.3723

Cattiaux J, Vautard R, Cassou R, Yiou P, Masson-Delmotte V, Codron F (2010) Winter 2010 in Europe: a cold extreme in a warming climate. Geophys Res Lett 37:L20704

Cavalieri DJ, Parkinson CL (2012) Arctic sea ice variability and trends, 1979-2010. Cryosphere 6:881-889

Cavalieri DJ, Parkinson CL, Gloersen P, Comiso JC, Zwally HJ (1999) Deriving long-term time series of sea ice cover from satellite passive-microwave multisensory data sets. J Geophys Res 104:15803-15814

Cheng B, Zhang Z, Vihma T, Johansson M, Bian L, Li Z, Wu H (2008) Model experiments on snow and ice thermodynamics in the Arctic Ocean with CHINARE2003 data. J Geophys Res 113:C09020

Cheng B, Mäkynen M, Similä M, Rontu L, Vihma T (2013) Modelling snow and ice thickness in the coastal Kara Sea, Russian Arctic. Ann Glaciol 54:62. doi:10.3189/2013AoG62A180

Christensen JH, Hewitson B, Busuioc A et al (2007) Regional climate projections. In: Solomon et al (eds) Climate Change 2007: The Physical Science Basis. Contribution of Working Group I to the Fourth Assessment Report of the Intergovernmental Panel on Climate Change. Cambridge University Press, Cambridge

Chung CE, Cha H, Vihma T, Räisänen P, Decremer D (2013) On the possibilities to use atmospheric reanalyses to evaluate the warming structure in the Arctic. Atmos Chem Phys 13:11209-11219 
Cohen J, Barlow M, Kushner P, Saito K (2007) Stratosphere - troposphere coupling and links with Eurasian land - surface variability. J Clim 20:5335-5343

Cohen J, Foster J, Barlow M, Saito K, Jones J (2010) Winter 2009-2010: a case study of an extreme Arctic Oscillation event. Geophys Res Lett 37:GL044256

Cohen JL, Furtado JC, Barlow MA, Alexeev VA, Cherry JE (2012a) Arctic warming, increasing snow cover and widespread boreal winter cooling. Environ Res Lett 7:014007. doi:10.1088/1748-9326/7/1/014007

Cohen JL, Furtado JC, Barlow M, Alexeev VA, Cherry JE (2012b) Asymmetric seasonal temperature trends. Geophys Res Lett 39:L04705

Comiso JC, Parkinson CL, Gersten R, Stock L (2008) Accelerated decline in the Arctic sea ice cover. Geophys Res Lett 35:L01703

Croci-Maspoli M, Schwierz C, Davies HC (2007) Atmospheric blocking: space-time links to the NAO and PNA. Clim Dyn 29:713-725

Cullather RI, Bromwich DH, Serreze MC (2000) The atmospheric hydrologic cycle over the Arctic basin from reanalyses. Part I: comparison with observations and previous studies. J Clim 13:923-937

Davini P, Cagnazzo C, Gualdi S, Navarra A (2012) Bidimensional diagnostics, variability, and trends of Northern Hemisphere blocking. J Clim 25:6496-6509

Deser C, Magnusdottir G, Saravanan R, Phillips A (2004) The effects of North Atlantic SST and sea ice anomalies on the winter circulation in CCM3. Part II: direct and indirect components of the response. J Clim 17:877-889

Deser C, Tomas R, Alexander M, Lawrence D (2010) The seasonal atmospheric response to projected Arctic sea ice loss in the late twenty-first century. J Clim 23:333-351

Ebner L, Schröder D, Heinemann G (2011) Impact of Laptev Sea flaw polynyas on the atmospheric boundary layer and ice production using idealized mesoscale simulations. Polar Res 30:7210. doi:10. 3402/polar.v30i0.7210

Eden P (2011) December 2010 Coldest December since 1890. Weather 66: i-iv. doi:10.1002/wea.690

Esau IN (2007) Amplification of turbulent exchange over wide Arctic leads: large-eddy simulation study. J Geophys Res 112:D08109

Esau IN, Zilitinkevich SS (2010) On the role of the planetary boundary layer depth in the climate system. Adv Sci Res 4:63-69

Farrell SL, Kurtz N, Connor LN, Elder BC, Leuschen C, Markus T, McAdoo DC, Panzer B, Richter-Menge J, Sonntag JG (2012) A first assessment of IceBridge snow and ice thickness data over Arctic sea ice. IEEE Transact Geosci Remote Sens 50:2098-2111

Flanner MG, Shell KM, Barlage M, Perovich DK, Tschudi MA (2011) Radiative forcing and albedo feedback from the Northern Hemisphere cryosphere between 1979 and 2008. Nat Geosci 4:151-155

Francis JA, Hunter E (2007) Changes in the fabric of the Arctic's greenhouse blanket, Environ Res Lett 2. doi:10.1088/1748-9326/2/4/045011

Francis JA, Vavrus SJ (2012) Evidence linking Arctic amplification to extreme weather in mid-latitudes. Geophys Res Lett 39:L06801

Francis JA, Chan W, Leathers DJ, Miller JR, Veron DE (2009) Winter Northern Hemisphere weather patterns remember summer Arctic sea-ice extent. Geophys Res Lett 36:L07503

Ghatak D, Frei A, Gong G, Stroeve J, Robinson D (2010) On the emergence of an Arctic amplification signal in terrestrial Arctic snow extent. J Geophys Res 115:D24105

Ghatak D, Deser C, Frei A, Gong G, Phillips A, Robinson DA, Stroeve J (2012) Simulated Siberian snow cover response to observed Arctic sea ice loss, 1979-2008. J Geophys Res 117:D23108

Grassi B, Redaelli G, Visconti G (2013) Arctic sea-ice reduction and extreme climate events over the Mediterranean region. J Clim (in press). doi:10.1175/JCLI-D-12-00697.1

Graversen RG, Wang M (2009) Polar amplification in a coupled climate model with locked albedo. Clim Dyn 33:629-643

Graversen RG, Mauritsen T, Tjernström M, Källen E, Svensson G (2008a) Vertical structure of recent Arctic warming. Nature 451:53-56

Graversen RG, Mauritsen T, Tjernström M, Källen E, Svensson G (2008b) Reply. Nature 455:E4-E5

Graversen RG, Mauritsen T, Drijfhout S, Tjernstrom M, Mårtensson S (2011) Warm winds from the Pacific caused extensive Arctic sea-ice melt in summer 2007. Clim Dyn. doi:10.1007/s00382-010-0809-z

Guo D, Gao Y, Bethke I, Gong D, Johannessen OM, Wang H (2013) Mechanism on how the spring Arctic sea ice impacts the East Asian summer monsoon. Theor Appl Climatol, published online 23 March 2013. doi:10.1007/s00704-013-0872-6

Hardiman SC, Kushner PJ, Cohen J (2008) Investigating the ability of general circulation models to capture the effects of Eurasian snow cover on winter climate. J Geophys Res 113:D21123

Hawkins E, Sutton R (2009) The potential to narrow uncertainty in regional climate predictions. Bull Am Meteor Soc 90:1095-1107 
Helfrich S, McNamara D, Ramsay B, Baldwin T, Kasheta T (2007) Enhancements to, and forthcoming developments in the interactive multisensor snow and ice mapping system (IMS). Hydrol Process 21:1576-1586

Higgins ME, Cassano JJ (2009) Impacts of reduced sea ice on winter Arctic atmospheric circulation, precipitation, and temperature. J Geophys Res 114:D16107

Holland MM, Bitz CM, Tremblay B, Bailey DA (2008) The role of natural versus forced change in future rapid summer Arctic ice loss. In: DeWeaver ET, Bitz CM, Tremblay L-B (eds) Arctic sea ice decline: observations, projections, mechanisms, and implications. Geophys Monogr Ser, 180. AGU, Washington, DC, pp 133-150

Honda M, Yamazaki K, Tachibana Y, Takeuchi K (1996) Influence of Okhotsk sea-ice extent on atmospheric circulation. Geophys Res Lett 23:3595-3598

Honda M, Yamazaki K, Nakamura H, Takeuchi K (1999) Dynamic and thermodynamic characteristics of atmospheric response to anomalous sea-ice extent in the Sea of Okhotsk. J Clim 12:3347-3358

Honda M, Inoue J, Yamane S (2009) Influence of low Arctic sea-ice minima on anomalously cold Eurasian winters. Geophys Res Lett 36:L08707

Hurrell JW (1995) Decadal trends in the North Atlantic Oscillation: regional temperatures and precipitation. Science 269:676-679

Ineson S et al (2011) Solar forcing of winter climate variability in the Northern Hemisphere. Nature Geosci 4:753-757

Inoue J, Enomoto T, Miyoshi T, Yamane S (2009) Impact of observations from Arctic drifting buoys on the reanalysis of surface fields. Geophys Res Lett 36:L08501

Inoue J, Hori ME, Takaya K (2012) The role of Barents Sea ice in the wintertime cyclone track and emergence of a warm-Arctic cold-Siberian anomaly. J Clim 25:2561-2568

Jaeger EB, Seneviratne SI (2011) Impact of soil moisture-atmosphere coupling on European climate extremes and trends in a regional climate model. Clim Dyn 36:1919-1939

Jaiser R, Dethloff K, Handorf D, Rinke A, Cohen J (2012) Impact of sea ice cover changes on the Northern Hemisphere atmospheric winter circulation. Tellus A 64:11595

Jakobson E, Vihma T, Palo T, Jakobson L, Keernik H, Jaagus J (2012) Validation of atmospheric reanalyzes over the central Arctic Ocean. Geophys Res Lett 39:L10802

Kapsch ML, Graversen RG, Tjernström M (2013) Springtime atmospheric energy transport and the control of Arctic summer sea-ice extent. Nat Clim Change 3:744-748

Karpechko A, Manzini E (2012) Stratospheric influence on tropospheric climate change in the Northern Hemisphere. J Geophys Res 117. doi:10.1029/2011JD017036

Kattsov V, Ryabinin V, Overland J, Serreze M, Visbeck M, Walsh J, Meier W, Zhang X (2010) Arctic sea ice change: a grand challenge of climate science. J Glaciol 56:1115-1121

Kay JE, L'Ecuyer T, Gettelman A, Stephens G, O'Dell C (2008) The contribution of cloud and radiation anomalies to the 2007 Arctic sea ice extent minimum. Geophys Res Lett 35:L08503

Kay JE, Raeder K, Gettelman A, Anderson J (2011) The boundary layer response to recent Arctic sea ice loss and implications for high-latitude climate feedbacks. J Clim 24:428-447

Kidson J, Taschetto AS, Thompson DWJ, England MH (2011) The influence of Southern Hemisphere seaice extent on the latitude of the mid-latitude jet stream. Geophys Res Lett 38:L15804

Kumar A, Perlwitz J, Eischeid J, Quan X, Xu T, Zhang T, Hoerling M, Jha B, Wang W (2010) Contribution of sea ice loss to Arctic amplification. Geophys Res Lett 37:L21701

Kwok R, Rothrock DA (2009) Decline in Arctic sea ice thickness from submarine and ICESat records: 1958-2008. Geophys Res Lett 36:L15501

L'Heureux ML, Kumar A, Bell GD, Halpert MS, Higgins RW (2008) Role of the Pacific-North American (PNA) pattern in the 2007 Arctic sea ice decline. Geophys Res Lett 35:L20701

Larkin NK, Harrison DE (2005) On the definition of El Niño and associated seasonal average U.S. Weather anomalies. Geophys Res Lett 32:L13705

Laxon SW, Peacock N, Smith D (2003) High interannual variability of sea ice thickness in the Arctic region. Nature 425:947-950

Ledley TS (1988) A coupled energy balance climate sea ice model: impact of sea ice and leads on climate. J Geophys Res 93:15919-15932

Liu Z, Alexander M (2007) Atmospheric bridge, oceanic tunnel, and global climate teleconnections. Rev Geophys 45:45.2005L

Liu J, Curry JA, Wang H, Song M, Horton RM (2012) Impact of declining Arctic sea ice on winter snowfall. Proc Natl Acad Sci USA 109:4074-4079

Lüpkes C, Vihma T, Birnbaum G, Wacker U (2008a) Influence of leads in sea ice on the temperature of the atmospheric boundary layer during polar night. Geophys Res Lett 35:L03805 
Lüpkes C, Gryanik VM, Witha B, Gryschka M, Raasch S, Gollnik T (2008b) Modeling convection over arctic leads with LES and a non-eddy-resolving microscale model. J Geophys Res 113:C09028

Lüpkes C, Vihma T, Jakobson E, König-Langlo G, Tetzlaff A (2010) Meteorological observations from ship cruises during summer to the central Arctic: a comparison with reanalysis data. Geophys Res Lett 37:L09810

Lüpkes C, Vihma T, Birnbaum G, Dierer S, Garbrecht T, Gryanik VM, Gryschka M, Hartmann J, Heinemann G, Kaleschke L, Raasch S, Savijärvi H, Schlünzen KH, Wacker U (2012) Mesoscale modelling of the Arctic atmospheric boundary layer and its interaction with sea ice. In: Lemke P, Jacobi HW (eds) Arctic Climate Change-The ACSYS Decade and Beyond, Atmospheric and Oceanographic Sciences Library, vol. 43. doi:10.1007/978-94-007-2027-5

Magnusdottir G, Deser C, Saravanan R (2004) The Effects of North Atlantic SST and sea ice anomalies on the winter circulation in CCM3. Part I: main features and storm track characteristics of the response. J Clim 17:857-876

Makshtas AP (1991) The heat budget of arctic ice in the winter. Int. Glaciol. Soc, Cambridge $77 \mathrm{pp}$

Makshtas A, Atkinson D, Kulakov M, Shutilin S, Krishfield R, Proshutinsky A (2007) Atmospheric forcing validation for modeling the central Arctic. Geophys Res Lett 34:L20706

Maksimovich E, Vihma T (2012) The effect of surface heat fluxes on interannual variability in the spring onset of snow melt in the central Arctic Ocean. J Geophys Res 117:C07012

Markus T, Stroeve JC, Miller J (2009) Recent changes in Arctic sea ice melt onset, freeze up and melt season length. J Geophys Res 114:C12024

Maslanik JA, Fowler C, Stroeve J, Drobot S, Zwally HJ, Yi D, Emery WJ (2007) A younger, thinner ice cover: increased potential for rapid, extensive ice loss. Geophys Res Lett 34:L24501

Meier WN, Gerland S, Granskog MA, Key JR, Haas C, Hovelsrud GK, Kovacs K, Makshtas A, Michel C, Perovich D, Reist JD, van Oort BEH (2011) Chapter 9: Sea ice. In: AMAP (2011) Snow, Water, Ice and Permafrost in the Arctic (SWIPA): Climate Change and the Cryosphere. Arctic Monitoring and Assessment Programme (AMAP), Oslo, Norway, xii $+538 \mathrm{pp}$

Mesquita MDS, Hodges KI, Atkinson DA, Bader J (2011) Sea-ice anomalies in the Sea of Okhotsk and the relationship with storm tracks in the Northern Hemisphere during winter. Tellus A 63:312-323

Moore GWK, Renfrew IA (2012) Cold European winters: interplay between the NAO and the East Atlantic mode. Atmos Sci Let 13:1-8

Niinimäki N (2008) Talvi oli Suomen mittaushistorian leudoin (The winter was mildest during the observational record in Finland, in Finnish). Ilmastokatsaus 2/2008, Finnish Meteorological Institute 13:3

Notz D (2009) The future of ice sheets and sea ice: between reversible retreat and unstoppable loss. Proc Natl Acad Sci USA 106:20590-20595

Ogi M, Yamazaki K, Wallace JM (2010) Influence of winter and summer surface wind anomalies on summer Arctic sea ice extent. Geophys Res Lett 37:L07701

Orsolini YJ, Kvamstø NG (2009) Role of Eurasian snow cover in wintertime circulation: decadal simulations forced with satellite observations. J Geophys Res 114:D19108

Orsolini YJ, Senan R, Benestad RE, Melsom A (2012) Autumn atmospheric response to the 2007 low Arctic sea ice extent in coupled ocean-atmosphere hindcasts. Clim Dyn 38:2437-2448

Osborn TJ (2011) Winter 2009/2010 temperatures and a record-breaking North Atlantic Oscillation index. Weather 66:19-21

Outten SD, Esau I (2012) A link between Arctic sea ice and recent cooling trends over Eurasia. Clim Change 110:1069-1075

Overland JE, Wang M (2010) Large-scale atmospheric circulation changes associated with the recent loss of Arctic sea ice. Tellus 62A:1-9

Overland JE, Wang M, Walsh JE, Christensen JH, Kattsov VM, Champan WL (2011a) Climate model projections for the Arctic. In: AMAP (2011) Snow, Water, Ice and Permafrost in the Arctic (SWIPA): Climate Change and the Cryosphere. Arctic Monitoring and Assessment Programme (AMAP), Oslo, Norway. xii +538 pp

Overland JE, Wood KR, Wang M (2011b) Warm Arctic cold continents: climate impacts of the newly open Arctic Sea. Polar Res 30:15787

Overland JE, Francis JA, Hanna E, Wang M (2012) The recent shift in early summer Arctic atmospheric circulation. Geophys Res Lett 39:L19804

Park H, Walsh JE, Kim Y, Nakai T, Ohata T (2012) The role of declining Arctic sea ice in recent decreasing terrestrial Arctic snow depths. Polar Sci. doi:10.1016/j.polar.2012.10.002

Parkinson CL, Cavalieri DJ (2008) Arctic sea ice variability and trends, 1979-2006. J Geophys Res 113:C07003

Parkinson CL, Comiso JC (2013) On the 2012 record low Arctic sea ice cover: combined impact of preconditioning and an August storm. Geophys Res Lett 40:1356-1361 
Peings Y, Magnusdottir G (2013) Response of the wintertime Northern Hemisphere atmospheric circulation to current and projected Arctic sea ice decline: a numerical study with CAM5. J Clim. doi:10.1175/ JCLI-D-13-00272.1 (in press)

Peings Y, Douville H, Alkama R, Decharme B (2011) Snow contribution to springtime atmospheric predictability over the second half of the twentieth century. Clim Dyn 37:985-1004

Peings Y, Saint-Martin D, Douville H (2012) A numerical sensitivity study of the Siberian snow influence on the northern annular mode. J Clim 25:592-607

Perovich DK, Richter-Menge JA, Jones KF, Light B (2008) Sunlight, water, and ice: extreme Arctic sea ice melt during the summer of 2007. Geophys Res Lett 35:L11501

Petoukhov V, Semenov VA (2010) A link between reduced Barents-Kara sea ice and cold winter extremes over northern continents. J Geophys Res 115:D21111

Pinto JO, Alam A, Maslanik JA, Curry JA, Stone RS (2003) Surface characteristics and atmospheric footprint of springtime Arctic leads at SHEBA. J Geophys Res 108:8051

Polyakov IV, Walsh JE, Kwok R (2012) Recent changes of Arctic multiyear sea ice coverage and the likely causes. Bull Am Meteorol Soc 93:145-151

Porter DF, Cassano JJ, Serreze MC (2012) Local and large-scale atmospheric responses to reduced Arctic sea ice and ocean warming in the WRF model. J Geophys Res 117:D11115

Radionov VF, Briazgin NN, Alexandrov EI (1996) Snow cover in the Arctic Basin (in Russian). 124 pp. Gidrometeoizdat, St. Petersburg. English translation. 1997. Tech. Rep. APLUW TR 9701. 98 pp. Polar Science Center University of Washington, Seattle

Rigor IG, Wallace JM (2004) Variations in the age of Arctic sea-ice and summer sea-ice extent. Geophys Res Lett 31:L09401

Rinke A, Maslowski W, Dethloff K, Clement J (2006) Influence of sea ice on the atmosphere: a study with an Arctic atmospheric regional climate model. J Geophys Res 111:D16103

Rinke A, Dethloff K, Dorn W, Handorf D, Moore JC (2013) Simulated Arctic atmospheric feedbacks associated with late summer sea ice anomalies. J Geophys Res 118. doi:10.1002/jgrd.50584

Robock A (2000) Volcanic eruptions and climate. Rev Geophys 38:191-219

Rothrock DA, Yu Y, Maykut GA (1999) Thinning of the Arctic sea-ice cover. Geophys Res Lett 26:3469-3472

Schweiger AJ, Zhang J, Lindsay RW, Steele M (2008) Did unusually sunny skies help drive the record sea ice minimum of 2007? Geophys Res Lett 35:L10503

Screen JA (2013) Influence of Arctic sea ice on European summer precipitation. Environ Res Lett 8:044015

Screen JA, Simmonds I (2010a) The central role of diminishing sea ice in recent Arctic temperature amplification. Nature 464:1334-1337

Screen JA, Simmonds I (2010b) Increasing fall-winter energy loss from the Arctic Ocean and its role in Arctic temperature amplification. Geophys Res Lett 37:L16797

Screen JA, Simmonds I (2012) Declining summer snowfall in the Arctic: causes, impacts and feedbacks. Clim Dyn 38:2243-2256

Screen JA, Simmonds I (2013) Exploring links between Arctic amplification and mid-latitude weather. Geophys Res Lett 40. doi:10.1002/grl.50174

Screen JA, Deser C, Simmonds I (2012) Local and remote controls on observed Arctic warming. Geophys Res Lett 39:L10709

Screen JA, Deser C, Simmonds I, Tomas R (2013a) Atmospheric impacts of Arctic sea-ice loss, 1979-2009: separating forced change from atmospheric internal variability, Clim Dyn, published online 15 June 2013, doi:10.1007/s00382-013-1830-9

Screen JA, Simmonds I, Deser C, Tomas R (2013b) The atmospheric response to three decades of observed Arctic sea ice loss. J Clim 26:1230-1248

Seager R, Kushnir Y, Nakamura J, Ting M, Naik N (2010) Northern Hemisphere winter snow anomalies: ENSO, NAO and the winter of 2009/10. Geophys Res Lett 37. doi:10.1029/2010GL043830

Sedlar J, Tjernström M, Mauritsen T, Shupe M, Brooks I, Persson POG, Birch CE, Leck C, Sirevaag A, Nicolaus M (2011) A transitioning Arctic surface energy budget: the impacts of solar zenith angle, surface albedo and cloud radiative forcing. Clim Dyn 37:1643-1660

Seierstad IA, Bader J (2009) Impact of a projected future Arctic Sea Ice reduction on extratropical storminess and the NAO. Clim Dyn 33:937-943

Serreze MC, Barry RG (2011) Processes and impacts of Arctic amplification: a research synthesis. Glob Planet Change 77:85-96

Serreze MC, Barrett AP, Stroeve JC, Kindig DN, Holland MM (2009) The emergence of surface-based Arctic amplification. Cryosphere 3:11-19

Serreze MC, Barrett AP, Cassano JJ (2011) Circulation and surface controls on the lower tropospheric temperature field of the Arctic. J Geophys Res 116:D07104 
Simmonds I, Rudeva I (2012) The great arctic cyclone of August 2012. Geophys Res Lett 39. doi:10.1029/ 2012GL054259

Singarayer JS, Bamber JL, Valdes PJ (2006) Twenty-first-century climate impacts from a declining Arctic sea ice cover. J Clim 19:1109-1125

Smith KL, Kushner PJ, Cohen J (2011) The role of linear interference in Northern Annular Mode variability associated with Eurasian snow cover extent. J Clim 24:6185-6202

Sokolova E, Dethloff K, Rinke A, Benkel A (2007) Planetary and synoptic scale adjustment of the Arctic atmosphere to sea ice cover changes. Geophys Res Lett 34:L17816

Spreen G, Kwok R, Menemenlis D (2011) Trends in Arctic sea ice drift and role of wind forcing: 1992-2009. Geophys Res Lett 38:L19501

Stammerjohn S, Massom R, Rind D, Martinson D (2012) Regions of rapid sea ice change: an interhemispheric seasonal comparison. Geophys Res Lett 39:L06501

Strey ST, Chapman WL, Walsh JE (2010) The 2007 sea ice minimum: impacts on the Northern Hemisphere atmosphere in late autumn and early winter. J Geophys Res 115:D23103

Stroeve J, Holland MM, Meier W, Scambos T, Serreze M (2007) Arctic sea ice decline: faster than forecast. Geophys Res Lett 34:L09501

Stroeve J, Serreze M, Drobot S, Gearhead S, Holland M, Maslanik J, Meier W, Scambos T (2008) Arctic sea ice extent plummets in 2007. EOS Transactions 89:13

Stroeve JC, Maslanik J, Serreze MC, Rigor I, Meier W, Fowler C (2011) Sea ice response to an extreme negative phase of the Arctic Oscillation during winter 2009/2010. Geophys Res Lett 38. doi:10.1029/ 2010GL045662

Stroeve JC, Serreze MC, Holland MM, Kay JE, Maslanik J, Barrett AP (2012) The Arctic's rapidly shrinking sea ice cover: a research synthesis. Clim Change 110:1005-1027

Sutton RT, Dong B (2012) Atlantic Ocean influence on a shift in European climate in the 1990s. Nature Geosci., published online 7 October 2012. doi:10.1038/NGEO1595

Tang Q, Zhang X, Yang X, Francis JA (2013) Cold winter extremes in northern continents linked to Arctic sea ice loss. Environ Res Lett 8:014036

Tetzlaff A, Kaleschke L, Lüpkes C, Ament F, Vihma T (2013) The impact of heterogeneous surface temperatures on the 2-m air temperature over the Arctic Ocean under clear skies in spring. Cryosphere 7:153-166

Thompson DWJ, Wallace JM (1998) The Arctic oscillation signature in the wintertime geopotential height and temperature fields. Geophys Res Lett 25:1297-1300

Thomson AM, Calvin KV, Smith SJ, Kyle GP, Volke A, Patel P, Delgado-Arias S, Bond-Lamberty B, Wise MA, Clarke LE, Edmonds JA (2011) RCP4.5: a pathway for stabilization of radiative forcing by 2100. Clim Change 109:77-94

Tjernström M, Zagar M, Svensson G, Cassano JJ, Pfeifer S, Rinke A, Wyser K, Dethloff K, Jones C, Semmler T, Shaw M (2005) Modelling the Arctic boundary layer: an evaluation of six ARCMIP regional-scale models using data from the SHEBA project. Boundary Layer Meteorol 117:337-381

Tjernström M, Sedlar J, Shupe MD (2008) How well do regional climate models reproduce radiation and clouds in the Arctic? An evaluation of ARCMIP simulations. J Appl Meteorol Climatol 47:2405-2422

Valkonen T, Vihma T, Doble M (2008) Mesoscale modelling of the atmospheric boundary layer over the Antarctic sea ice: a late autumn case study. Mon Wea Rev 136:1457-1474

Vihma T (1995) Subgrid parameterization of surface heat and momentum fluxes over polar oceans. J Geophys Res 100:22625-22646

Vihma T, Uotila J, Cheng B, Launiainen J (2002) Surface heat budget over the Weddell Sea: buoy results and comparisons with large-scale models. J Geophys Res 107:3013

Vihma T, Jaagus J, Jakobson E, Palo T (2008) Meteorological conditions in the Arctic Ocean in spring and summer 2007 as recorded on the drifting ice station Tara. Gephys Res Lett 35:L18706

Vihma T, Tisler P, Uotila P (2012) Atmospheric forcing on the drift of Arctic sea ice in 1989-2009. Geophys Res Lett 39:L02501

Vihma T, Pirazzini R, Renfrew IA, Sedlar J, Tjernström M, Nygård T, Fer I, Lüpkes C, Notz D, Weiss J, Marsan D, Cheng B, Birnbaum G, Gerland S, Chechin D, Gascard JC (2013) Advances in understanding and parameterization of small-scale physical processes in the marine Arctic climate system: a review. Atmos Chem Phys Discuss 13. doi:10.5194/acpd-13-1-2013

Walsh JE, Overland JE, Groisman PY, Rudolph B (2011). Arctic Climate: Recent Variations. In: AMAP (2011) Snow, Water, Ice and Permafrost in the Arctic (SWIPA): Climate Change and the Cryosphere. Arctic Monitoring and Assessment Programme (AMAP), Oslo, Norway. xii +538 pp

Warren SG, Rigor IG, Untersteiner N, Radionov VF, Bryazgin NN, Aleksandrov YL, Colony R (1999) Snow depth on Arctic sea ice. J Clim 12:1814-1829 
Woodgate RA, Weingartner T, Lindsay R (2010) The 2007 Bering Strait oceanic heat flux and anomalous Arctic sea-ice retreat. Geophys Res Lett 37:L01602

Woollings T (2008) Vertical structure of anthropogenic zonal-mean atmospheric circulation change. Geophys Res Lett 35:L19702

World Meteorological Organization (1970) WMO sea-ice nomenclature: terminology, codes and illustrated glossary. Secretariat of the World Meteorological Organization, Geneva

Wu B, Zhang R, Wang B, D'Arrigo R (2009) On the association between spring Arctic sea ice concentration and Chinese summer rainfall. Geophys Res Lett 36:L09501

Wu B, Zhang R, D’Arrigo R, Su J (2013) On the relationship between winter sea ice and summer atmospheric circulation over Eurasia. J Clim 26:5523-5536

Yang S, Christensen JH (2012) Arctic sea ice reduction and European cold winters in CMIP5 climate change experiments. Geophys Res Lett 39:L20707

Yang XY, Fyfe JC, Flato GM (2010) The role of poleward energy transport in Arctic temperature evolution. Geophys Res Lett 37:L14803

Zhang X, Sorteberg A, Zhang J, Gerdes R, Comiso JC (2008) Recent radical shifts of atmospheric circulations and rapid changes in Arctic climate system. Geophys Res Lett 35:L22701

Zhang X, Lu C, Guan Z (2012) Weakened cyclones, intensified anticyclones and recent extreme cold winter weather events in Eurasia. Environ Res Lett 7. doi:10.1088/1748-9326/7/4/044044

Zhang J, Lindsay R, Schweiger A, Steele M (2013) The impact of an intense summer cyclone on 2012 Arctic sea ice retreat. Geophys Res Lett 40:720-726

Zhao P, Zhang X, Zhou X, Ikeda M, Yin Y (2004) The sea ice extent anomaly in the North Pacific and its impact on the East Asian summer monsoon rainfall. J Clim 17:3434-3447 